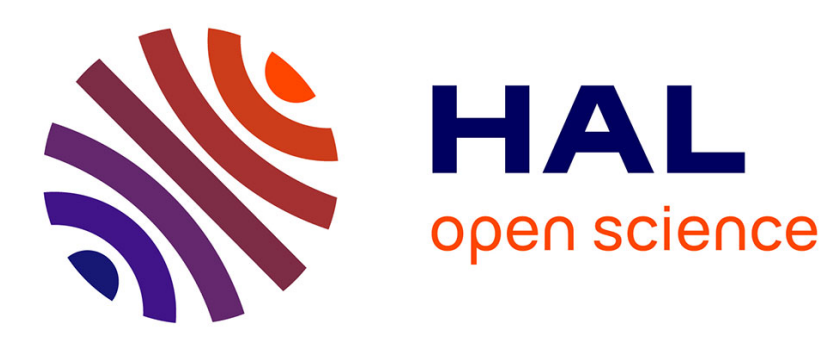

\title{
Embayed intermediate volcanoes on Venus: implications for the evolution of the volcanic plains
}

I. López

\section{To cite this version:}

I. López. Embayed intermediate volcanoes on Venus: implications for the evolution of the volcanic plains. Icarus, 2011, 10.1016/j.icarus.2011.02.022 . hal-00743836

\section{HAL Id: hal-00743836 \\ https://hal.science/hal-00743836}

Submitted on 21 Oct 2012

HAL is a multi-disciplinary open access archive for the deposit and dissemination of scientific research documents, whether they are published or not. The documents may come from teaching and research institutions in France or abroad, or from public or private research centers.
L'archive ouverte pluridisciplinaire HAL, est destinée au dépôt et à la diffusion de documents scientifiques de niveau recherche, publiés ou non, émanant des établissements d'enseignement et de recherche français ou étrangers, des laboratoires publics ou privés. 


\section{Accepted Manuscript}

Embayed intermediate volcanoes on Venus: implications for the evolution of the volcanic plains

\section{López}

PII:

S0019-1035(11)00080-7

DOI:

10.1016/j.icarus.2011.02.022

Reference:

YICAR 9739

To appear in:

Icarus

Received Date: $\quad 22$ January 2010

Revised Date: $\quad 17$ February 2011

Accepted Date: $\quad 21$ February 2011

Please cite this article as: López, I., Embayed intermediate volcanoes on Venus: implications for the evolution of the volcanic plains, Icarus (2011), doi: 10.1016/j.icarus.2011.02.022

This is a PDF file of an unedited manuscript that has been accepted for publication. As a service to our customers we are providing this early version of the manuscript. The manuscript will undergo copyediting, typesetting, and review of the resulting proof before it is published in its final form. Please note that during the production process errors may be discovered which could affect the content, and all legal disclaimers that apply to the journal pertain. 
Embayed intermediate volcanoes on Venus: implications for the evolution of the volcanic plains.

I. López.

${ }^{1}$ Departamento de Biología y Geología, Escuela Superior de Ciencias Experimentales y Tecnología. Universidad Rey Juan Carlos, 28933. Móstoles, Madrid, Spain.

E-mail:

ivan.lopez@urjc.es

Pages: 34

Figures: 7

Tables: 1 
RUNNING HEAD: Embayed intermediate volcanoes on Venus. CORRESPONDENT AUTHOR:

Iván López Ruiz-Labranderas

Área de Geología-ESCET.

Departamental II-Despacho 268.

Universidad Rey Juan Carlos.

28933 Móstoles, Madrid.

Spain.

E-mail: $\underline{\text { ivan.lopez@urjc.es }}$ 


\section{ABSTRACT.}

Volcanoes on Venus are classified according to size with studies on the stratigraphic position of large volcanoes proposing that most of the large volcanoes postdate the regional volcanic materials. Some studies regarding intermediate volcanoes proposed that some of these volcanic features could be large volcanoes with embayed flow aprons, a situation that would alter the previous stratigraphic considerations about large volcanoes on Venus.

In this work I analyze the global population of embayed intermediate-size volcanoes and compare their summits with that of other edifices classified as large volcanoes. Intermediate-size volcanoes are considered embayed when: 1) flows from another source clearly overlap the volcano slopes, and 2) display scarps related to flankfailure processes but with the associated collapse deposits being absent (i.e. interpreted as covered). As result of the survey 88 embayed intermediate-size volcanoes have been catalogued and integrated into a Geographic Information System. These embayed volcanoes have summit sizes and characteristics similar to large volcanoes and, therefore, could be interpreted as possible large volcanoes with their flow aprons embayed. Embayment materials for these volcanoes include all the units present in the history of the volcanic plains and would indicate that this type of central volcanic edifice would occur throughout the geologic history recorded in the Venusian plains.

Key Words: Venus, Volcanism, Geological processes 


\section{Introduction}

Magellan data show that the surface of Venus is dominated by volcanic landforms including large flow fields and a wide range of volcanic edifices that occur in different magmatic and tectonic environments (e.g. Head et al., 1992; Crumpler et al., 1997;

Crumpler and Aubele, 2000).

Classification of volcanic edifices follows a scheme, outlined after the first radar imaging of the northern hemisphere of the planet by the Venera 15 and 16 probes, based on the size of the edifice including the central edifice and the apron of flows (e.g. Barsukov et al., 1986; Slyuta and Krevlavsky, 1990). According to these initial observations, done before the global high resolution radar mapping of the surface carried out by the Magellan mission, volcanoes were divided into three classes: 1) large volcanoes $(\bullet 100 \mathrm{~km}) ; 2)$ intermediate volcanoes $(\bullet 20 \mathrm{~km}$ and $<100 \mathrm{~km}$; and 3) small volcanoes $(<20 \mathrm{~km})$. This size-based classification was used in later studies of the global volcanic activity of Venus based on Magellan data (e.g. Head et al., 1992; Crumpler et al., 1997). The resulting catalogues and databases (for the most recent published version of the Magellan Volcano Catalogue see Crumpler and Aubele, 2000) were the base for the study of the distribution, evolution of the different volcanic features and their implications for the geologic evolution of Venus. Some volcanic types seem to be preferentially related to a particular size range, for instance, steep-side domes and modified or fluted volcanoes are mostly in the intermediate size category (e.g. Pavri et al., 1992; Bulmer and Guest, 1996), but in general this size-based classification does not have any geologic significance (i.e. recurring characteristics occur throughout the three classes; Crumpler et al., 1997). 
In all the different models that try to explain the geological evolution of Venus, volcanic activity plays an important role as the source for the material that has resurfaced the planet. Nevertheless, the style and timing of the volcanic activity varies between the different models. Two different views on the geologic evolution of Venus are being tested through geologic mapping of surface materials: a) models that explain the evolution of Venus through a series of epochs which represent different volcanic and tectonic processes at a global scale, and proposed that the stratigraphy records a shift in volcanic style, with formation of rifts, volcanoes and coronae superimposed on the plains (e.g. Basilevsky et al., 1997; Basilevsky and Head, 1998a; Basilevsky and Head, 2000a); and b) models proposing that the different volcanic and tectonic processes occurred throughout the period of time represented by surface materials, but not restricted to a particular time of Venus history (e.g. Guest and Stofan, 1999; Stofan et al., 2005).

The study of large volcanoes, in particular their age and stratigraphic position, played an important role in the evaluation of these models (e.g. Price and Suppe, 1994; Namiki and Solomon, 1994; Basilevsky and Head, 2000b). Using crater densities to date the whole surface occupied by large volcanoes, Price et al. (1996) determined that crater densities on large volcanoes were about half of the global average. In another work that used a different database, Namiki and Solomon (1994) reach a similar conclusion regarding the density of impact craters on large volcanoes. According to these works, large volcanoes formed in a high position in the regional and local stratigraphic sections, and thus appear to postdate regional plains and predate only the youngest extensional tectonic activity and associated volcanism. The population of large volcanoes used on these studies was based on the pre-Magellan size-based classification (i.e. large volcanoes were defined based on the presence of a clear apron of flows surrounding the volcanic edifice). 
Detailed geologic mapping of volcanic features on the Venusian plains has revealed that some structures on the plains, classified as intermediate volcanoes, could indeed be larger features whose lower flanks are partially covered by volcanic flows from another source (Guest and Stofan, 1999; Crumpler et al., 1997; Tanaka et al., 1997). If there is a representative population of such partially embayed intermediate volcanoes, and these were indeed original large volcanoes that predate the embaying material, the high relative stratigraphic position of large volcanoes in the history of the volcanic plains would need to be reconsidered, with important implications in the ongoing debate about the different models that explain the geologic evolution of Venus.

In this work I have studied the global population of intermediate volcanoes and determine the number of them that could be partially embayed edifices, and therefore underestimated in size regarding their original morphology/characteristics (i.e. possible large volcanoes). I have also compared their summit morphologies and characteristics to those of large volcanoes to identify common characteristics related to volcanic evolution (e.g. presence and size of summit calderas). The study also compiles information regarding the nature of the embaying material (e.g. regional plain material, corona-related flows) and discusses the possible implications on the geologic evolution of the Venusian volcanic plains.

\section{Data and methodology}

The study of the global population of embayed intermediate volcanoes was carried out based on the most recent Magellan Volcanic Catalog (MVC) database compiled by Crumpler and Aubele (2000). In the database there is a total of 289 recognized intermediate volcanoes divided in four classes: a) "generic" intermediate size volcanoes are similar to simple large shield volcanoes (55 examples); b) fluted or 
modified domes (57 examples); c) radial flows (24 examples) and; d) steep-sided domes (153 examples).

An additional analysis of the Venus surface carried out with high resolution images added some examples not included in the published database, many of them are $<20 \mathrm{~km}$ and therefore at the lower limit size of the category, but they show summit characteristics similar to larger observed volcanoes. The study was completed with published Venus geologic maps and data from the regularly updated Gazetteer of Planetary Nomenclature (http://planetarynames.wr.usgs.gov/), especially in those cases of large volcanoes used to compare summit characteristics and renamed after mapping.

The MVC treats large volcanic calderas or paterae as a particular class, including both large and intermediate-size volcanic features. For this reason I have not included this type of volcanic feature in the study and should be the focus of future studies to evaluate its role in the evolution of the volcanic plains.

Geologic analysis of selected examples was carried out using NASA's Magellan S-band (12.6 cm wavelength) synthetic aperture radar (SAR) and altimetry data (e.g. Ford et al., 1993). Data used for the study include: (1) full resolution (F-BIDR); 75-100 $\mathrm{m} /$ pixel) both right and left-illuminated radar images); (2) Magellan altimetry ( $<8 \mathrm{~km}$ along-track by $20 \mathrm{~km}$ across-track with $<30$-m average vertical accuracy which improves to $<10 \mathrm{~m}$ in smooth areas; Ford et al., 1993); and (3) synthetic stereo images constructed after Kirk et al. (1992) using NIH-Image macros developed by Duncan Young. All images were obtained through the USGS Map-a-Planet website. SAR images were viewed in both normal and inverted (negative) modes.

\section{[FIGURE 1]}

Criteria for characterization of embayed intermediate volcanoes. 
I have used two criteria to define an intermediate volcano as partially embayed, that resulted in two different classes in the database (Table I): a) Type I: volcanoes with evidence of volcanic material from another source that embays and/or overlaps the lower volcano slopes (Figure 1a). This type is characterized by the presence of capped volcanoes were the summit and caldera is surrounded by younger materials that cover the lower volcanic flanks. This first type of embayed intermediate volcanoes correspond to the type of feature discussed in Guest and Stofan (1999), who considered that this type of embayed intermediate volcano could be a large volcano in origin but with the radial apron of flows covered by younger materials. b) Type II: volcanoes with steep scarps and morphological evidences of flank failure but without the associated debris apron (Figure 1b). One of the diagnostic features of large volcanic debris avalanche deposits on Earth is the distinctive hummocky terrain that they produce (Siebert, 1984). The hummocky terrains are reminiscent of the debris-avalanche deposit and are clear in radar images as they are composed of large blocks, or hummocks (>1 km), which produce a rough texture surface at the base of the scarps (i.e. high reflectivity in radar images; Figure 1b). Evidence of flank failure processes is widespread on Venus with over 100 debris aprons identified in Magellan images (Bulmer and Guest, 1996). According to these authors most of the slope failures appear to have occurred after the volcano activity ceased so the volcanic flows that embay or cover these deposits should be from a different volcanic source. A key assumption in the interpretation of Venus' rock record is that liquid water has not played a role in shaping its surface. Primary evidence for this view is rooted in the extremely dehydrated state of the lower atmosphere (Donahue et al., 1997) and lithosphere (Mackwell et al., 1998), and present surface temperature of $\sim 460{ }^{\circ} \mathrm{C}$ (Crisp and Titov, 1997). In absence of water-related erosion, the large block-size deposits associated with collapse remain unaltered during 
long periods of time. When these deposits are completely absent near a clear collapse scarp on the volcano summit and there is evidence of volcanism in the area, I interpret that it is the presence of younger volcanic deposits that obscures the deposit.

Type II examples are mostly classified as fluted domes and steep-side domes. In a global study of the stratigraphy and distribution of these volcanic types, Ivanov and Head (1999) found that these volcanic morphologies are "old" features in the evolution of the volcanic plains.

Determination of the nature and origin of the embaying material for each example was carried out considering published cartographic materials: USGS Investigation Series geologic maps, geologic maps in research articles and abstracts of the Annual NASA's Mappers Meetings, where preliminary results of the ongoing Venus mapping are presented on an annual basis. For those examples located in areas were no published data are available I have made a study based on full resolution radar images and VMAP scale base maps to determine the nature and origin of the embaying material. Due to the characteristics of SAR data the ability to identify unit boundaries based on a change in appearance in SAR images alone sometimes is difficult. Embaying material determined in the study as undivided volcanic materials is defined by the same cartographic criteria as the unit fu (Geologic map of the Rusalka Planitia Quadrangle (V25); Young and Hansen, 2003) and unit hu (Geologic map of the Helen Planitia Quadrangle (V52); López and Hansen, 2008), that is, composite units formed by volcanic materials that cannot be differentiated due to homogenization processes (Arvidson et al., 1992) and/or lack of clear primary structures (e.g. clear radar boundaries). Similar materials have been mapped as regional plain materials in other published maps based on the presence of regionally distributed deformational structures like wrinkle ridge (e.g. unit pr in the Geologic map of the Barrymore Quadrangle; Johnson et al., 1999). This relation is based in the idea that wrinkle ridge formed contemporaneously across the volcanic 
plains (e.g. Basilevsky et al., 1997; Basilevsky and Head, 1998a; Basilevsky and Head, 2000a), although this is a matter of discussion (e.g. McGill, 2004b).

\section{Results}

Number and distribution of partially embayed intermediate volcanoes.

The global study of partly embayed intermediate volcanoes resulted in 88 examples distributed across the planet (see Table I and Figure 2a). 25 of these examples correspond to the Type I class and 63 to the Type II class.

\section{[Table 1]}

The global distribution of partly embayed intermediate volcanoes is similar to large volcanoes (Figure 2a and b) with a clear clustering in the Beta-Atla-Themis region (e.g. Crumpler et al., 1993; Crumpler et al., 1997). This region covers approximately 20 percent of Venus' surface with a higher presence of volcanic and tectonic features when compared with the rest of the Venus surface (e.g. Crumpler et al., 1997).

\section{[FIGURE 2]}

With regard to altitude partly embayed volcanoes are preferentially located in the mesolands (Figures 2 and 3), between 0 and $2 \mathrm{~km}$ with regard to the Mean Planetary Radius $(6051.8 \mathrm{~km})$. For the two types of embayed volcanoes considered in this work, most of the examples are inside that topographic province (21 of the Type I and 55 of the Type II; Figure 3), with just 7 examples located in the lowlands (below the Mean Planetary Radius) and 5 in the highlands ( $>2 \mathrm{~km}$ above the Mean Planetary Radius). 
None of the examples located in the lowlands are in the central part of these large volcanic basins but in the peripheral areas, near the mesolands (Figure 2a).

\section{[FIGURE 3]}

General characteristics of the partially embayed intermediate volcanoes.

Intermediate volcanoes considered in this study are characterized based exclusively on summit size and morphology. The size of most of the observed examples ranges between 20 and $100 \mathrm{~km}$, although some examples with summit size between 15$20 \mathrm{~km}$ have been considered because they show embayment and morphology equivalent to larger observed volcanic features. These volcanoes are different to the small clustered volcanoes that form shields fields (Aubele, 1996, Addington, 2001; Crumpler et al, 1997) and the shield terrain (Hansen, 2005).

The size and morphology of embayed intermediate volcanoes are equivalent to the summits of large volcanoes in their lower size range (see Figures 4 and 5). Large volcanoes are described as being composed of a main edifice and an outer apron, with a break in the slope values between them $\left(1-3^{\circ}\right.$ for the main edifice and $<1^{\circ}$ for the outer apron; Stofan et al., 2001). Embayment of the observed volcanoes should take place on the lower part of the edifice, in the transition to the surrounding volcanic plains. In the case of the Type II embayed volcanoes flank failure processes take place in areas of high slope (i.e. main edifice), with the debris apron spreading downslope over the outer apron. Younger volcanic materials then would cover the outer apron and the previous collapse-related deposit (look at Table I to see the nature of the embaying material for each example). 
Embayed intermediate volcanoes are mostly low volcanic shields (e.g. Figure 4c, 4d and 4e), tholus-like edifices (e.g. Figure $4 \mathrm{a}$ and $4 \mathrm{~b}$ ) and flat-topped volcanoes (e.g. Figure 4f, 4g. $4 \mathrm{~h}$ and $4 \mathrm{i}$ ). Due to the higher slopes of the last two classes (i.e. more prone to flank failure processes) most of the Type II embayed volcanoes are tholus and/or flat-topped volcanoes ( $\mathrm{a}, \mathrm{b}, \mathrm{f}, \mathrm{g}, \mathrm{h}$ and $\mathrm{i}$ in Figure 4). Type I are mostly related to low shields (c,d and e in Figure 3).

Most of the intermediate volcanoes considered embayed in this work display calderas on their summits, evidence for a high-level magma reservoir with a comparable size to the observed caldera (e.g. Ryan et al., 1983). Many of the embayed intermediate volcanoes display caldera complexes that consist of multiple overlapping calderas.

These overlapping calderas are indicative of a rich and complex volcanic history that implies multiple events of filling of the volcanic reservoir, eruption and depletion of the magma chamber and subsequent collapse (ej. Figure $4 \mathrm{a}$ and $4 \mathrm{~g}$ ). If caldera size is indicative of the size of the underlying reservoir and therefore of the volume of magma involved in the volcanic activity associated to the volcano (e.g. Wood, 1984), most of the embayed intermediate volcanoes show physical evidence that suggest the presence of equivalent magma reservoirs to that of many large volcanoes of the lower size range (Figure 5), even although we cannot observe the volcano-related flows and materials that originated from such magma reservoirs.

\section{[FIGURE 4]}

\section{Comparison with large volcanoes.}


As discussed above, the summits of embayed intermediate volcanoes show similar morphology and size to some volcanic features catalogued as large volcanoes (see Figures 4 and 5; Magellan Volcanic Feature Catalogue of Crumpler and Aubele, 2000). Common morphologies in large volcanoes include flat-topped summits (Figures $5 \mathrm{a}, 5 \mathrm{~b}, 5 \mathrm{c}$ and $5 \mathrm{~g}$ ), some of them are stellate in plan view (e.g. Figure $5 \mathrm{f}$ ) and have domical or tholus-like summits (Figures 5d, 5e, 5h and 5i). All these morphologies and sizes are analogous to those of embayed intermediate volcanoes of Figure 4 suggesting that similar volcanic processes at the same scale are operating in both volcanic classes independently of their size.

One of the large volcanoes of Figure 5, Ne Ngam Mons (43s257.5), located in the plains of northern Helen Planitia, has been studied in detail during the geologic mapping of the Helen Planitia Quadrangle (López and Hansen, 2008; López et al., 2008). The main topographic edifice has a diameter of about $25 \mathrm{~km}$ and it is slightly elongated along a north-south trend (Figure $5 \mathrm{~g}$ ). In the summit there is a simple circular caldera with a small cone or dome that likely represents post-caldera floor volcanic activity restricted to the summit. This main edifice has slopes of $0.6-0.7^{\circ}$ and is surrounded by an outer lava apron extending up to $180 \mathrm{~km}$ with slopes that are about $0.08-0.3^{\circ}$. This topographic shape, similar to other large volcanoes on Venus (e.g. Keddie and Head, 1995; Stofan et al., 2001), has been interpreted as the result of complex eruptive histories involving frequent, low-effusion rate, summit eruptions accompanied by less frequent but voluminous flank eruptions (e.g. Stofan et al, 2001). Located to the northeast of Ne Ngam Mons is 33n262IV (Figure 4b). This intermediate volcano displays a summit topped with a large complex caldera. From the volcanic point of view there are little differences between this volcano and $\mathrm{Ne} \mathrm{Ngam}$ Mons; both are central edifices with calderas on their summits. If caldera size is related to the size of the magma chamber, both edifices could be the source of a similar volume 
of emitted magma; caldera and summit size of 33n262IV even exceeds that of Ne Ngam Mons. The main difference between these two volcanic edifices is the presence of radial flows. In the case of 33n262IV the associated flows cannot be observed but the volcano has three clear scarps that are responsible for its approximate triangular shape. No collapse related deposits are related to these scarps suggesting that they are covered by younger volcanic material. This volcanic edifice is located near Parga Chasmata and their associated coronae. Flows that originate in this fracture system and the related tectonomagmatic features flowed downslope and reached the flanks of 33n262IV, thus covering the collapse-related deposits and the possible radial flows originated from this volcanic edifice (López and Hansen, 2008). Comparison of these two examples makes clear how geologic setting of the volcanic feature plays an important role on the observation/occurrence of associated radial flows related to the central volcano summit.

Another volcano located in the Helen Planitia Quadrangle (V52) is Monoshi Tholus (37.7s252). According to the existing databases the size of the summit of this volcano is $15 \mathrm{~km}$ in diameter. Geologic mapping carried out in this area interpreted some long flows $(>100 \mathrm{~km}$ ) to be related to this volcanic edifice (unit Flow material from Monoshi Tholus; López and Hansen, 2008), illustrating that many of the intermediate volcanoes could be related to volcanic flows that were not initially identified due to lack of detailed geologic mapping, or alternatively, due to homogeneization processes or volcanic embayment. In this particular case the presence of shields that postdate the flows close to the summit also difficult to establish the relation between the flows and their source.

\section{[FIGURE 5]}

Nature of the embaying materials. 
Besides the global survey of partly embayed volcanoes, I have made a study of the embaying materials based on published maps and specific observations of examples located in areas without published works. In most of the cases, embaying materials come from a unique source but in two examples there are multiple sources for the embaying materials.

The embaying material is classified according to the interpretations used in the different maps (e.g. regional plains) and the proposed/observed origin of the material (e.g. corona-related flows). The different embaying material classes determined in this study are: a) shield material: plain material characterized by the presence of numerous small-size distributed volcanoes that resurface great areas in a point-source style (e.g. Aubele and Slyuta, 1990; Hansen, 2005). According to some studies on the stratigraphic position of shield material, this unit is located low in the history of the volcanic plains (unit psh; Basilevsky et al., 1997; Basilevsky and Head, 1998a; Basilevsky and Head, 2000a), just after tessera terrain and other deformed terrains and before the emplacement of the regional plains. Other studies argue for a time transgressive formation relative to deformation on the volcanic plains (Hansen, 2005); b) regional plains material: materials of different origin that cover most of the volcanic plains form these units. These regional volcanic materials are defined in the different maps according to their surface properties (e.g. homogeneous, smooth, mottled, radar-bright, etc) or by the presence of deformational structures (e.g. densely lineated plains, plains with wrinkle ridges, etc). In most of the published maps the source of the plains material is not obvious (e.g. wrinkle ridged plain material in the Beta Regio quadrangle (V17); Basilevsky, 2008). According to models that argue for the existence of a global stratigraphy on Venus, these volcanic materials represent a global extensive period of basaltic volcanism that occurred after tessera formation related to a global resurfacing 
event. This extensive style of volcanism later evolved to more localized floods and formation of large volcanoes (Basilevsky et al., 1997; Basilevsky and Head, 1998a; Basilevsky and Head, 2000a). Alternative models propose that plains are not emplaced in this extensive mode but that different units formed by different volcanic styles occur throughout the history represented by the exposed materials (Guest and Stofan, 1999); c) undivided plains material: I have used this category for the embaying materials in areas where geologic maps are not published and a clear source of the embaying material cannot be observed. The undivided plains material category is considered here analogous to units fu (flow material undifferentiated; Young and Hansen, 2003) and hu (heterogeneous material, undivided; López and Hansen, 2008) in the Rusalka Planitia Quadrangle and the Helen Planitia Quadrangle respectively. That is, materials related to a composite of individual local to regional volcanic events without clear stratigraphic significance that cannot be confidently differentiated with available data and actual geologic mapping. In published maps where undivided plain materials have been defined (see for example unit hu in the Helen Planitia Quadrangle; López and Hansen, 2008) they spatially correlate with regional plains materials in surrounding areas (unit pr in the Barrymore Quadrangle; Johnson et al, 1999), although geologic interpretation in both cases is different; d) chasmata/coronae related materials: These units are formed by flows that are related to fracture systems and associated coronae in mesolands or by isolated coronae located in the volcanic plains. According to models that argue for the existence of a global stratigraphy on Venus, formation and evolution of coronae occurred after the emplacement of regional plains and spanned a significant part of the geologic history of Venus (Basilevsky et al., 1997; Basilevsky and Head, 1998b), with materials that range from lower densely fractured plains (unit Pdf) to the upper coronarelated lobate flows (unit Pl). Other models argue that corona formation is not confined to a single period in the geologic history of Venus and that different geologic histories 
are found in different studied coronae (Copp et al., 1998). A third view on the corona evolution on Venus propose that there are two different groups of coronae on Venus: an older population coeval with regional plains and a younger population formed in relationship to the mayor fracture systems of Venus (Chapman and Zimbelman, 1998). Of the 25 intermediate volcanoes that are embayed by chasmata/coronae materials just five of them are related to isolated coronae and the rest occur near fracture systems and/or associated coronae; e) volcano related materials: These units are formed by volcano related flows. These volcano-related flows are included in the lobate flow unit (unit Pl) of the global stratigraphic model, postdating regional plains materials and reflecting a decreasing and more localized volcanic activity on the volcanic plains (Basilevsky et al., 1997; Basilevsky and Head, 1998a; Basilevsky and Head, 2000a). In the alternative models volcano-related activity takes place throughout the whole geologic history of Venus (Guest and Stofan, 1999); and f) crater related materials: they are thought to be the youngest materials on the surface of Venus. Nevertheless, there is no way to constrain the absolute age of craters and as far as we know a crater is just younger than the material on which the impact occurred. In the case documented in this work, crater-related outflows, though to be the result of partial melting during impact (e.g. Chadwick and Schaber, 1993), are embaying the intermediate volcano.

Taking into account the observations regarding the nature of the embaying materials, it seems clear that the formation of embayed intermediate volcanoes occurred throughout the history of the plains represented by surface materials (Figure 6). A third of the embayed intermediate volcanoes ( 8 embayed by shield materials and 22 by regional plains materials) are postdated by materials that are related to early stages on the evolution of the regional volcanic plains (units psh and pwr; e.g. Basilevsky et al., 1997; Basilevsky and Head, 1998a; Basilevsky and Head, 2000a). Although I have considered undivided plains material as an independent class, in $69 \%$ of the volcanoes 
embayed by this class (18 of 26 examples) those embaying materials are flows deformed by wrinkle ridges, and analogous to regional plains material identified by other authors in existing maps (e.g. V59; Johnson et al., 1999). Thus, if we add those to the regional plains materials, 48 of 88 embayed intermediate volcanoes are predating volcanic materials located in the lower part of the global proposed stratigraphic column (Basilevsky et al., 1997; Basilevsky and Head, 1998a; Basilevsky and Head, 2000a).

The remaining examples are embayed by undivided plains materials not deformed by wrinkle ridges, chasmata/coronae- and volcano-related materials and crater outflow deposits, thought to represent younger materials on the evolution of the regional plains and therefore contemporaneous with formation of large volcanoes later on the history of the regional plains (lobate plains; e.g. Basilevsky et al., 1997; Basilevsky and Head, 1998a; Basilevsky and Head, 2000a).

[FIGURE 6]

\section{Discussion}

Implications for the stratigraphic position of the large volcanoes on the history of the volcanic plains.

According to global studies of crater densities on large volcanoes $(>100 \mathrm{~km})$, this class of volcanic feature is relatively young in the history of the volcanic plains (Namiki and Salomon, 1994; Price and Suppe, 1994; Price et al., 1996). The use of crater densities to determine the age of large volcanoes in these studies requires all the large volcanoes included in a global map unit to have a representative surface that could be 
dated using crater densities. This approximation implies the 'ab initio' presumption that all large volcanoes have a similar age.

Besides, these studies are based on the size-based classification of volcanic features established before the analysis of Magellan data (Barsukov et al., 1986; Slyuta and Krevlavsky, 1990). In this classification, inclusion of unmodified clear radial flow aprons in the definition of large volcanoes yields a population were processes that could produce changes in the primary characteristics of the volcanic flows are not considered. For example, time-related processes like weathering/homogeneization (e.g. Arvidson et al., 1992) could modify initial radar characteristics of the volcanic flows, leading to flows that could not be differentiated from the surrounding materials and the impossibility to delineate the extent of the flows. Other processes like volcanic embayment by younger flows also make it impossible to delimitate the original extent of the flows and therefore to classify a volcanic feature according to its initial size.

Other studies that use the size-based classification also conclude that large volcanoes are, for most of the cases, younger than the wrinkle-ridged regional plains (Basilevsky and Head, 2000b). These authors differentiated three classes of large volcanoes according to their relation with the regional plains: young (67.5\%), transitional or contemporaneous (16.5\%) and old (15\%). According to all the previous works, there was a change in volcanic style from extensive flood-type volcanic flows related to a global resurfacing event to more localized geologic processes like coronae, rifts, volcanoes and other features superimposed on the volcanic plains (e.g. Price et al., 1996; Basilevsky et al., 1997; Basilevsky and Head, 1998a; Basilevsky and Head, 2000a).

The study carried out here reveals the occurrence of a significant population of embayed intermediate volcanoes that could represent previous large volcanoes. These embayed intermediate volcanoes would be temporally analogous to those old large 
volcanoes of Basilevsky and Head (2000b). If this were the case, previous studies would be biased because considered just younger volcanic features that have a volcanic apron of well-defined flows without homogenization and/or volcanic embayment. According to this, large volcanoes of these studies are younger that the plains but just because possibly older volcanoes with homogenized flows were not identified, and therefore not taken into account in the study.

Observations regarding the existence of embayed intermediated volcanoes (Guest and Stofan, 1999; Crumpler et al., 1997; Tanaka et al., 1997) and the global study of their occurrence carried out here suggest a significant presence of possible old large volcanoes embayed by regional plain materials and would argue against the idea of large volcanoes only present in the 'recent' geologic history of the plains. As it has been discussed in the previous section, more that half of the embayed intermediate volcanoes are covered by regional plains materials and therefore predate these extensive materials thought to represent relative old materials in the evolution of the volcanic plains (i.e. shield materials and regional plains materials of the Rusalka Group; Basilevsky and Head, 2000a). From this study on the occurrence and distribution of embayed intermediate volcanoes (i.e. possible volcanoes $>100 \mathrm{~km}$ in origin), I consider that the formation of central large volcanoes took place throughout the history of the evolution of the volcanic plains and that there is not a clear shift in volcanic style from large scale flooding to central volcanism.

Classification of volcanic features in geologic studies.

According to the result of the work carried out studies of volcanic classes based exclusively on size should be reconsidered. Small volcanoes and shields fields seem to represent a class on their own based on their particular characteristics and their spatial 
association (i.e shield clustering). They also seem to represent an important resurfacing agent in the lowlands and have been considered as a particular geologic unit in published maps (e.g. Hansen, 2005; Aubele and Slyuta, 1990). In any case, higher resolution than existing Magellan radar data will be necessary to constrain volcanic processes and summit features of this volcanic class.

Large and intermediate volcanoes share common summit features that suggest the occurrence of similar volcanic processes in both categories. As we have seen in Figures 4 and 5, summit size and characteristics between these two volcanic classes are often similar. If the size of the summit caldera is proportional to the underlying magma reservoir, then the magma chamber of some intermediate volcanoes is equivalent to that of some large volcanoes, with some intermediate volcanoes even displaying larger calderas than many large volcanoes. The global distribution of possible embayed intermediate volcanoes is also similar to that of large volcanoes (Figures 2) and both, large and embayed intermediate volcanoes, are located mainly in the mesolands topographic province (Figure 3).

Some examples of volcanic morphologies are mostly included in the intermediate size class (e.g. steep-sided domes and fluted domes) but are also present with size $>100$ $\mathrm{km}$. Therefore I propose that for future studies of the volcanic activity of the volcanic plains both, large and intermediate volcanoes, should be considered together and differentiated in classes based in morphology (e.g. tholus, shields, steep-sided, etc).

Nevertheless, not all large volcanoes are analogous to embayed intermediate volcanoes and some of them could indeed be considered a group apart. Some large volcanoes that cover more that $500 \mathrm{~km}$ are thought to be related to the presence of underlying mantle plumes (e.g. Herrick et al., 2005; Stofan and Smrekar, 2005; Keddie and Head, 1995). Some of these volcanoes have similar sizes to those of coronae and have been defined as 'hybrid' features (Grindrod et al., 2006). Studies of areas where 
these two large tectonomagmatic features occur suggest that both, coronae and large volcanoes could be the surface expression of mantle plumes, but formed under lithospheres of different elastic thickness (McGovern and Solomon, 1998; McGill, 1994). Gravimetric study of some of these large volcanoes with a domical topographic expression carried out by Herrick et al. (2005) points to a strong correlation between an absence of postdating features and the presence of dynamic support by an underlying plume, suggesting that they are indeed young features. Therefore, these large volcanoes related to the existence of underlying mantle plumes and with common characteristics to coronae could be included in a particular class.

\section{Collapse features in large volcanoes.}

One of the classes of embayed intermediate volcanoes is defined on the base of presence of collapse-related scarps in the volcano flanks and the absence of related deposits (Type II). In a study of modified volcanic domes and their associated deposits, Bulmer and Guest (1996) determined that $80 \%$ of the observed volcanic domes on Venus have modified morphologies. Many of the domes studied by these authors are tholus-type volcanoes that have been included in this work as possible embayed intermediate volcanoes. Collapse related processes and deposits are common on the evolution of terrestrial volcanoes but have not been observed in studies of large volcanoes on Venus that used size-based classifications (e.g. McGovern and Solomon, 1998).

The global survey of embayed intermediate volcanoes also resulted in the identification of some volcanic features that could represent both, large volcanoes with a radial apron of flows $>100 \mathrm{~km}$ but also with evidence of lateral flank failure processes (Figure 7). One of the examples is 46n269FD, an intermediate volcano 
classified as fluted or modified dome in the Crumpler and Aubele (2000) database (Figure 7a). This volcano displays some radial lobate flows of intermediate backscatter that seem to be related to this volcanic feature. These flows reach more that $100 \mathrm{~km}$, and thus could be considered as a large feature according to the size-based classification. The debris-avalanche deposit (i.e. hummocky terrain; Figure 7b) is superposed on the radial apron of flows suggesting that lateral flank collapse occurred late in the volcanic cycle.

There are also some examples of large volcanoes with central summits that display steep flanks but without a clear apron of radial flows (e.g. Sapas Mons; Figure 7c). The two volcanic edifices in the summit of Sapas Mons display steep scarps but the related deposits are not clear in radar images. Flows radial to this summit extend for more than $400 \mathrm{~km}$. There is a small deposit of higher backscatter located to west of the southern summit feature that could represent a distal part of the hummocky terrain (Figure 7c), but younger flows obscure definite identification. Therefore, in this case the absence of a clear hummocky terrain associated with the steep scarp suggests that volcanic flows erupted on the volcano flanks are responsible for the embayment of the collapse-related deposit (i.e. volcanic embayment is not from a secondary source), and suggest that some volcanoes undergo cycles of construction-destruction similar to that described in terrestrial volcanoes (e.g. Canary Islands; Carracedo, 1994).

\section{[FIGURE 7]}

\section{Conclusions}

In this work I have studied the Venusian global population of embayed intermediate-size volcanoes that could represent large volcanoes that predate other 
volcanic materials. Intermediate-size volcanoes are considered embayed when: 1) flows from another source clearly overlap the volcano slopes (Type I), and 2) display scarps related to flank-failure processes but with the associated collapse deposits absent and interpreted as covered (Type II). As result of the survey 88 embayed intermediate-size volcanoes have been catalogued in a Geographic Information System. Of these, 48 are predating volcanic materials located in the lower part of the volcanic plains. The remaining examples are embayed by undivided plains materials not deformed by wrinkle ridges, chasmata/coronae- and volcano-related materials and crater outflow deposits, thought to represent younger materials on the evolution of the regional plains and therefore contemporaneous with formation of large volcanoes later on the history of the regional plains. This suggest that formation of central large volcanoes took place throughout the history of the evolution of the volcanic plains and that there is not a shift in volcanic style from large scale flooding to localized central volcanism, as suggested in the models that argue in favor of global synchronous events (Basilevsky et al., 1997; Basilevsky and Head, 1998a; Basilevsky and Head, 2000a).

Size-based classification of volcanic features was useful in the first stages of the study of Venus. Nevertheless, data of increased resolution from the Magellan mission showed that volcanoes classified according to size display similar summit morphology and evidence of common volcanic evolution. I argue here for a change in volcano classification that will consider intermediate and large volcanoes as a unique class with differences based in their summit features and volcanic evolution. Particular subclasses inside this lumped volcano group would include: shield volcanoes, tholus (i.e. domical features), flat-topped volcanoes and steep-sided domes. Large volcanoes that show 'hybrid' characteristics with coronae (e.g. annulus of concentric features) should be considered a class apart based in their morphology, evolution and the evidence for a dynamic plume support (e.g. Herrick et al., 2005). 
Type II embayed intermediate volcanoes could represent an important population of large volcanoes that undergo lateral sector collapse. These examples and the observation of some large volcanoes with collapse features suggest that these processes are as common on the evolution of large Venusian volcanoes as in their terrestrial and Martian counterparts.

\section{Acknowledgments}

I want to thank James Head and two anonymous reviewers for the carefully review of the initial work. I want to thank Dr. Javier Lillo for his carefully review of the initial version of the manuscript.

\section{References}

Addington, E. A., 2001, A stratigraphic study of small volcano clusters on Venus, Icarus, 149, p. 16-36.

Arvidson, R.E., Greely, R., Malin, M.C., Saunders, R.S., Izenberg, N., Plaut, J.J., Stofan, E.R., and Shepard, M.K., 1992. Surface modification of Venus as inferred from Magellan observations of plains, J. Geophys. Res. 97, 13303-13318.

Aubele, J.C., 1996. Akkruva small shield plains; definition of a significant regional plains unit on Venus. Lunar and Planetary Science Conference, v27, p. 49-50.

Aubele, J.C., and Slyuta, E.N., 1990, Small domes on Venus: Characteristics and origin: Earth, Moon, and Planets, v. 50/51, p. 493-532, doi: 10.1007/BF00142404.

Barsukov, V.L., Basilevsky, A.T., Burba, G.A., Bobina, N.N., Kryuchkov, V.P. V. P., Kuzmin, R. O., Nikolaeva, O. V., Pronin, A. A., Ronca, L. B., Chernaya, I. M., Shashkina, V. P., Garanin, A. V., Kushky, E. R., Markov, M. S., Sukhanov, A. L., 
Kotelnikov, V. A., Rzhiga, O. N., Petrov, G. M., Alexandrov, Y. N., Sidorenko, A. I., Bogomolov, A. F., Skrypnik, G. I., Bergman, M. Y., Kudrin, L. V., Bokshtein, I. M., Kronrod, M. A., Chochia, P. A., Tyuflin, Y. S., Kadnichansky, S. A., and Akim, E. L., 1986. The geology and geomorphology of the Venus surface as revealed by the radar images obtained by Veneras 15 and 16. Proceedings of the 17th Lunar and Planetary Science Conference, Part 2. J. Geophys. Res., 91, 378-398.

Basilevsky, A.T, 2008. Geologic map of the Beta Regio Quadrangle (V-17), Venus. U.S. Geological Survey Scientific Investigations Map 3023 [http://pubs.usgs.gov/sim/3023/].

Basilevsky, A.T. and Head, J.W., 2000a. Geologic units on Venus: evidence for their global correlation. Planet. Space. Sci., 48, 75-111.

Basilevsky, A.T. and Head, J.W., 2000b. Rifts and large volcanoes on Venus: Global assessment of their age relations with regional plains. J. Geophys. Res., 105, 24583-24611.

Basilevsky, A.T. and Head, J.W., 1998a. The geologic history of Venus: a stratigraphic view. J. Geophys. Res., 103, 8531-8544.

Basilevsky, A.T. and Head, J.W., 1998b. Onset time and duration of corona activity on Venus: stratigraphy and history from photogeologic study of stereo images. Earth, Moon and Planets., 76, 67-115.

Basilevsky, A.T., Head, J.W., Schaber, G.G. and Strom, R.G., 1997. The resurfacing history of Venus. In: Bougher, S.W., Hunten, D.M., and Phillips, R.J., (Eds.), Venus II: Geology, geophysics, atmosphere, and solar environment. Univ. of Arizona Press. Tucson, pp. 1047-1084.

Bleamaster, L.F. 2008. Geologic mapping of Isabella Quadrangle (V-50) and Helen Planitia, Venus. Abstracts of the Annual Meeting of Planetary Geologic Mappers, Flagstaff, AZ. NASA/CP-2008-215469. 
Bleamaster, L.F. 2007. Geologic mapping of Isabella Quadrangle (V-50) and Helen Planitia, Venus. Abstracts of the Annual Meeting of Planetary Geologic Mappers, Tucson, AZ. United States Geological Survey Open-File Report 2007-1233.

Brian, A.W., Stofan, E.R., and Guest, J.E., 2005. Geologic map of the Taussig Quadrangle (V-39), Venus. U.S. Geological Survey Scientific Investigations Map 2813 [http://pubs.usgs.gov/sim/2005/2813/].

Bulmer, M.H. and Guest, J.E., 1996. Modified volcanic domes and associated debris aprons on Venus. In: McGuire, W. J., A.P. Jones and J. Neuberg (Eds.), Volcano instability on the Earth and other planets. Geological Society Special Publication No 110. Geological Society of London, p.349-371.

Campbell, B.A., and Clark, D.A., 2006. Geologic map of the Mead Quadrangle (V-21), Venus: U.S. Geological Survey Scientific Investigations Map 2897 [http://pubs.usgs.gov/sim/2006/2897/].

Carracedo, J.C., 1994. The Canary Islands: an example of structural control on the growth of large oceanic-island yolcanoes. J. Volcanol. Geotherm. Res, 60, 225-241.

Chadwick, D.J., and Schaber, G.G., 1993. Impact crater outflows on Venus: Morphology and emplacement mechanisms, J. Geophys. Res., 98, E11, 20891-20902.

Chapman, M.G., 1999. Geologic/Geomorphic map of the Galindo Quadrangle (V40), Venus: U.S. Geological Survey Scientific Investigations Map 2613

[http://geopubs.wr.usgs.gov/i-map/i2613].

Chapman, M.G. and Zimbelman, J.R. 1998. Corona associations and their implications for Venus. Icarus. 132, 344-361.

Copp, D.L., Guest, J.E. and Stofan, E.R. 1998. New insights into coronae evolution: mapping on Venus. J. Geophys. Res., 103, 19401-19417. 
Crisp, D. and D. Titov, 1997, The thermal balance of Venus atmosphere, in Bougher, S.W., Hunten, D.M., and Phillips, R.J. (eds), Venus II: Geology, Geophysics, Atmosphere, and Solar Wind Environment: Tucson, University of Arizona Press, p. 353-384.

Crown, D.A., Stofan, E.R. and Bleamaster, L.F. 2008. Geologic mapping of the Guinevere Planitia Quadrangle of Venus. Abstracts of the Annual Meeting of Planetary Geologic Mappers, Flagstaff, AZ. NASA/CP-2008-215469.

Crumpler, L.S., Head, J.W., and Aubele, J.C., 1993. Relation of mayor volcanic center concentration on Venus to global tectonic patterns. Science, 261, 591-595.

Crumpler L.S., Aubele, J.C., Senske, D.A., Keddie, S.T., Magee, K.P., and Head, J.W., 1997. Volcanoes and centers of volcanism on Venus. In: Bougher, S.W., Hunten, D.M., and Phillips, R.J., (Eds.), Venus II: Geology, geophysics, atmosphere, and solar environment. Univ. of Arizona Press. Tucson, pp. 697-756.

Crumpler L.S. and J.C. Aubele, J.C., 2000. Volcanism on Venus. In Sigurdsson, Houghton, H.B., McNutt, S.R., Rymer, H., Stix, J., (Eds), Encyclopedia of volcanoes. Academic Press, pp. 727-770.

Donahue, T.M., D.H. Grinspoon, R.E. Hartle and R.R. Hodges, Jr., 1997, Ion/neutral escape of hydrogen and deuterium: evolution of water, in Bougher, S.W., Hunten, D.M., and Phillips, R.J. (eds), Venus II: Geology, Geophysics, Atmosphere, and Solar Wind Environment: Tucson, University of Arizona Press, p. 385-414.

Ford, J.P., Plaut, J.J., Weitz, C.M., Farr, T.G., Senske, D.A., Stofan, E.R., Michaels, G., and Parker, T.J., 1993. Guide to Magellan Image Interpretation, National Aeronautics and Space Administration Jet Propulsion Laboratory Publication, 93-24. 287 pp. 
Grindrod, P.M., Stofan, E.R., Brian, A.W., and Guest, J.E., 2006. The geological evolution of Atai Mons, Venus: a volcano-corona 'hybrid'. J. Geol. Soc. London, 163, $265-275$.

Guest, J.E. and Stofan, E.R., 1999. A new view of the stratigraphic history of Venus. Icarus, 139, 55-66.

Hansen, V.L., 2009. Geologic map of the Niobe quadrangle (V-23), Venus: U.S. Geological Survey Scientific Investigations Map 3025 [http://pubs.usgs.gov/sim/2006/2897/].

Hansen, V.L., 2005, Venus's shield-terrain: Geological Society of America Bulletin, v. 117 , no. $5 / 6$, p. 808-822.

Hansen, V.L. and Tharalson, E., (in press). Geologic map of the Agnesi Quadrangle, Venus. U.S. Geological Survey Scientific Investigations Map xxxx [http://pubs.usgs.gov/sim/2006/2897/].

Head, J.W., Crumpler, L.S., Aubele, J.C., Guest, J.E., and Saunders, R.S., 1992. Venus volcanism: Classification of volcanic features and structures, associations, and global distribution from Magellan data. J. Geophys. Res., 97, 13153-13197.

Herrick, R.R. Dufek, J., and McGovern, P.J., 2005. Evolution of large volcanoes on Venus. J. Geophys. Res., 110, E01002, doi:10.1029/2004JE002283.

Ivanov, M.A. and Head, J.W. 1999. The stratigraphic and geographic distribution of steep-sided domes on Venus: Preliminary results from regional geologic mapping and implications for their origin, J. Geophys. Res., 104 (E8), 18,907-18,924.

Ivanov, M. A. and Head, J.W., 2008. Geologic map of the Meskhent Tessera quadrangle (V-3), Venus: U.S. Geological Survey Scientific Investigations Map 3018 [http://pubs.usgs.gov/sim/3018/]. 
Ivanov, M. A. and Head, J.W., 2006. Geologic map of the Mylitta Fluctus Quadrangle (V-61), Venus: U.S. Geological Survey Scientific Investigations Map 2920 [http://pubs.usgs.gov/sim/2006/2920].

Johnson, J.R., Komatsu, G., and Baker, V.R., 1999. Geologic map of the Barrymore Quadrangle (V-59), Venus: U.S. Geological Survey Scientific Investigations Map 2610 [http://geopubs.wr.usgs.gov/i-map/i2610/].

Keddie, S.T. and Head, J.W., 1995. Formation and evolution of volcanic edifices on the Dione Regio Rise, Venus. J. Geophys. Res., 100, 11729-11754.

Kirk, R., L. Soderblom and E. Lee, 1992. Enhanced visualization for interpretation of Magellan radar data: supplement to the Magellan special issue. J. Geophys. Res., 97, 16371-16380.

López, I., and Hansen, V.L., 2008. Geologic map of the Helen Planitia Quadrangle (V-52), Venus: U.S. Geological Survey Scientific Investigations Map 3026 [http://pubs.usgs.gov/sim/3026/].

López, I., Lillo, J., Hansen, V.L., 2008. Regional fracture patterns around volcanoes: possible evidence for volcanic spreading on Venus. Icarus, 195, 523-536.

Mackwell, S. J., Zimmerman, M. E., and Kohlstedt, D. L., 1998, Hightemperature deformation of dry diabase with application to tectonics on Venus: Jounal of Geophysical Research, v. 103, p. 975-984.

McGill, G.E., 1994. Hotspot evolution and Venusian tectonic style. J. Geophys. Res., 99, 23149-23161.

McGill, G.E., 2000. Geologic map of the Sapho Patera Quadrangle (V-20), Venus. U.S. Geological Survey Scientific Investigations Map 2637 [http://geopubs.wr.usgs.gov/i-map/i2637/]. 
McGill, G.E., 2004a. Geologic map of the Bereghinya Planitia Quadrangle (V-8), Venus. U.S. Geological Survey Scientific Investigations Map 2794 [http://pubs.usgs.gov/imap/i2794/].

McGill, G.E., 2004b. Tectonic and stratigraphic implications of the relative ages of venusian plains and wrinkle ridges, Icarus, 172, 603-612

McGill, G.E. and Bridges, N.T., 2002. Geologic Map of the Kaiwan Fluctus Quadrangle (V-44), Venus. U.S. Geological Survey Scientific Investigations Map 2747 [http://pubs.usgs.gov/imap/i2747].

McGovern, P.J. and Solomon, S.C., 1998. Growth of large volcanoes on Venus: Mechanical models and implications for structural evolution. J. Geophys. Res., 103, 11071-11101.

Namiki, N. and Solomon, S.C., 1994. Impact crater densities on volcanoes and coronae on Venus: Implications for volcanic resurfacing. Science, 265, 929-933.

Pavri, B., Head, J.W., Klose, K.B., and Wilson, L., 1992. Steep-sided domes on Venus: Characteristics, geologic setting, and eruption conditions from Magellan data. J. Geophys. Res., 97, 13445-13478.

Price, M.H., Watson, G., Suppe, J., and Brankman, C., 1996. Dating volcanism and rifting on Venus using impact crater densities. J. Geophys. Res., 101, 4657-4671.

Price, M.H., and Suppe, J., 1994. Mean age of rifting and volcanism on Venus deduced from impact crater densities. Nature, 372, 756-759.

Rosenberg, E. and McGill, G.E., 2001. Geologic map of the Pandrosos Dorsa Quadrangle (V-5), Venus. U.S. Geological Survey Scientific Investigations Map 2721 [http://pubs.usgs.gov/imap/i2721/].

Ryan, M. P., Blevins, J.Y.K., Okamura, A.T., and Koyanagi, R.Y., 1983. Magma 
reservoir subsidence mechanics: Theoretical summary and application to Kilauea volcano. J. Geophys. Res. 88, 4147-4181.

Senske, D.A. 2008. Geologic mapping of the Juno Chasma Quadrangle, Venus: Establishing the relation between rifting and volcanism. Abstracts of the Annual Meeting of Planetary Geologic Mappers, Flagstaff, AZ. NASA/CP-2008-215469.

Senske, 2006. Geologic mapping of the Juno Chasma Quadrangle (V-47), Venus. Abstracts of the Annual Meeting of Planetary Geologic Mappers, Nampa, ID. United States Geological Survey Open-File Report 2006-1263.

Siebert, L., 1984. Large volcanic debris avalanches: Characteristics of source areas, deposits, and associated eruptions. Journal of Volcanology and Geothermal Research, 22, 163-197.

Slyuta, E.N. and Kreslavsky, M.A., 1990. Intermediate (20-100 km) sized volcanic edifices on Venus. Abstracts of the Lunar and Planetary Science Conference XXI: 1174-1175.

Stofan, E.R., Brian, A.W. and Guest, J.E., 2005. Resurfacing styles and rates on Venus: assessment of 18 Venusian quadrangles. Icarus, 173, 312-321.

Stofan, E.R. and Smrekar, S.E., 2005. Large topographic rises, coronae, large flow fields and large volcanoes on Venus: evidence for mantle plumes?, in Foulger, G.R., Natland, J.H., Presnall, D.C., and Anderson, D.L. (eds), Plates, Plumes and Paradigms. Geological Society of America Special Paper 388, pp. 841-861.

Stofan, E. R. and Guest, J.E., 2003. Geologic map of the Aino Planitia Quadrangle (V-46), Venus: U.S. Geological Survey Scientific Investigations Map 2729 [http://pubs.usgs.gov/imap/i2729/].

Stofan, E.R., Guest, J.E., and Copp, D.L., 2001. Development of large volcanoes on Venus: constraints from Sif, Gula and Kunapipi montes. Icarus, 152, 75-95. 
Tanaka K.L., Senske, D.A., Price, M., and Kirk, R.L., 1997. Physiography, geomorphic/geologic mapping, and stratigraphy of Venus. In: Bougher, S.W., Hunten, D.M., and Phillips, R.J., (Eds.), Venus II: Geology, geophysics, atmosphere, and solar environment. Univ. of Arizona Press. Tucson, pp. 667-694.

Wood, C.A., 1984. Calderas: a planetary perspective. J. Geophys. Res. 89, 83918406.

Young, D., and Hansen, V.L., 2003. Geologic map of the Rusalka Planitia Quadrangle (V-25), Venus. U.S. Geological Survey Scientific Investigations Map 2783 [http://pubs.usgs.gov/imap/i2783/]. 


\section{FIGURES AND TABLES.}

Figure 1. Examples of the criteria used to consider an intermediate volcano as embayed: a) Type I: embayment (volcanic on-lap) of the lower summit; and b) Type II: presence of clear scarps related to flank failure processes without the associated debris apron (and therefore interpreted as covered on their lower summit). All images are Magellan left-looking radar images in normal mode with a resolution of $75 \mathrm{~m} /$ pixel

Figure 2. a) Global distribution of large volcanoes (Crumpler and Aubele, 2000). b) Global distribution of embayed Intermediate volcanoes (this work). The base map in both cases is a simplification of the Venusian topography with three classes representing the main geomorphic provinces: lowlands, mesolands and highlands.

Figure 3. Frequency distribution of embayed intermediate volcanoes in the different topographic provinces of Venus: lowlands (below mean planetary radius), mesolands (0- $2 \mathrm{~km}$ above mean planetary radius), highlands ( $>2 \mathrm{~km}$ above mean planetary radius).

Figure 4. Examples of embayed intermediate volcanoes observed in the volcanic plains. a) 12n071IV; b) 33n262IV; c) 31n218IV; d) 18n070IV; e) 59n082IV; f) 14n070IV; g) 38n043IV; h) 23s250IV; i) 70n096IV. All images are Magellan leftlooking radar images in normal mode with a resolution of $75 \mathrm{~m} /$ pixel.

Figure 5. Summits of large volcanoes with similar characteristics to the embayed intermediate volcanoes described in the text: a) $18 \mathrm{~s} 293 \mathrm{LV}$; b) $19.5 \mathrm{n} 344 \mathrm{LV}$; c) 22n344.5LV; d) 35n277LV; e) Justitia Tholus (28.5s296.5); f) Kwannon Tholus (26.3s296.8); g) Ne Ngam Mons (43s257.5); h) Nijole Mons (45n185); i) Nipa Tholus (8.4n255.7). All images are Magellan left-looking radar images in normal mode with a resolution of $75 \mathrm{~m} /$ pixel. NOTE: Justitia Tholus is not catalogued as large volcano but 
the study carried out here revealed the presence of radial apron of flows and size $>100$ $\mathrm{km}$.

Figure 6. Embaying material classes. Note that the sum of the examples for each class exceeds the number of examples cited in the text. This is due to some examples being embayed by more than one material at the same (see table for details).

Figure 7. a) General view of 46n269FD. Arrows indicate the presence of radial lobate flows. b) Detail of the summit and the two collapse-related hummocky deposits. Both images are Magellan left-looking radar images in normal mode with a resolution of $75 \mathrm{~m} /$ pixel. c) Detail of the summit of Sapas Mons $\left(8.5^{\circ} \mathrm{S} / 188^{\circ} \mathrm{E}\right)$. This large volcano displays a complex summit with multiple scarps on their edifices and a possible buried hummocky terrain associated to the southern summit. The image is a Magellan leftlooking radar image with a resolution of $75 \mathrm{~m} / \mathrm{pixel}$.

Table I. List of the embayed intermediate volcanoes determined in the study (coordinates, type of embayed volcano, morphology and embayment material). The asterisks mark the examples present in Crumpler and Aubele (2000). 


\section{Type I}

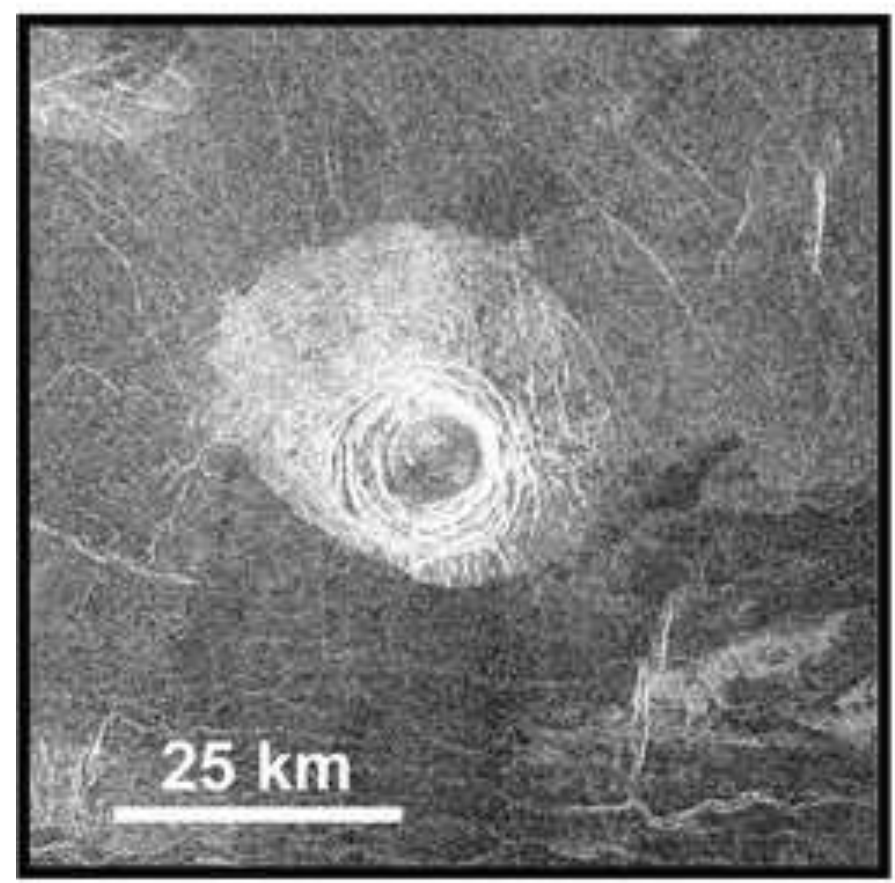

Type II

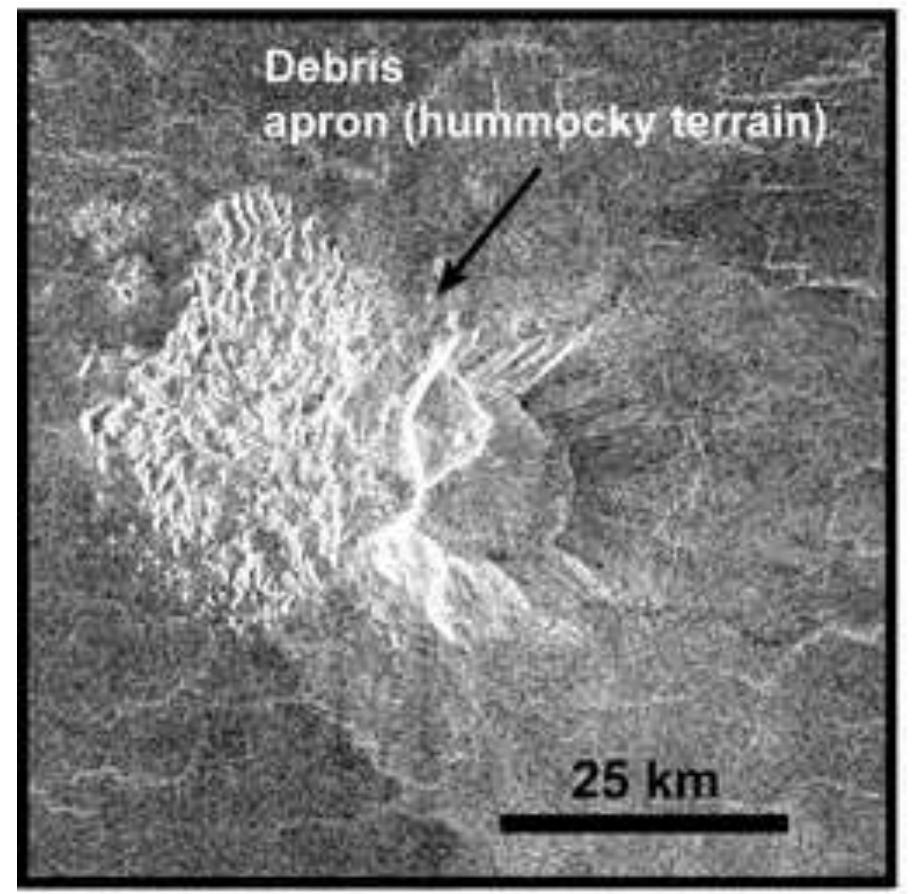

Not embayed

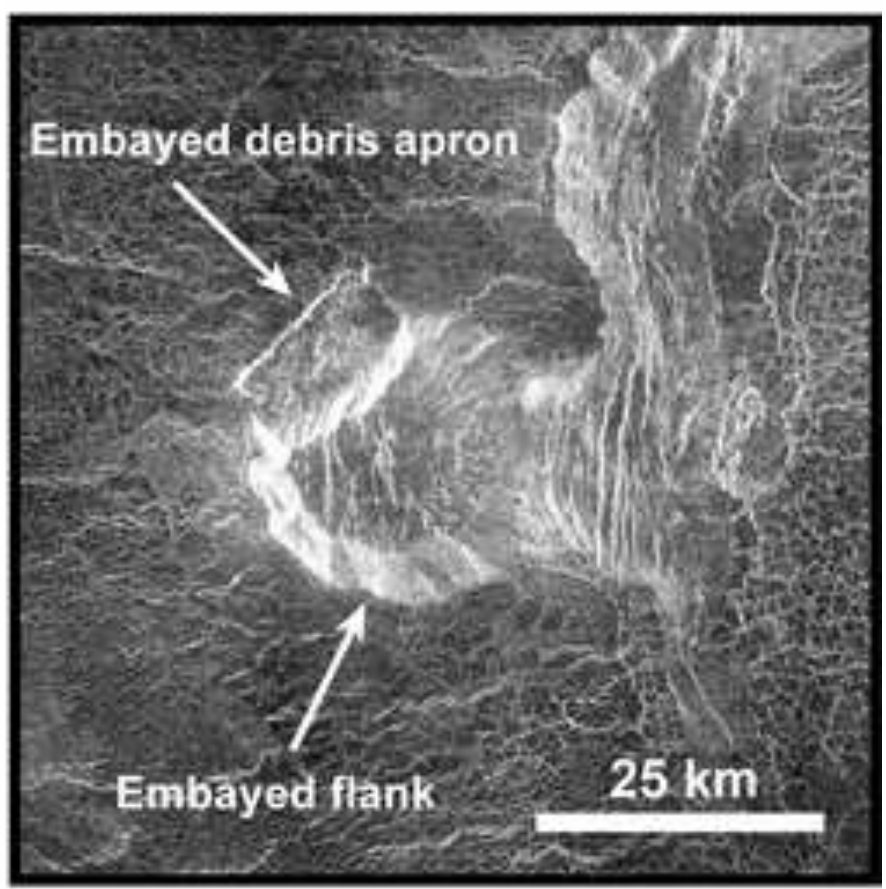

Embayed 

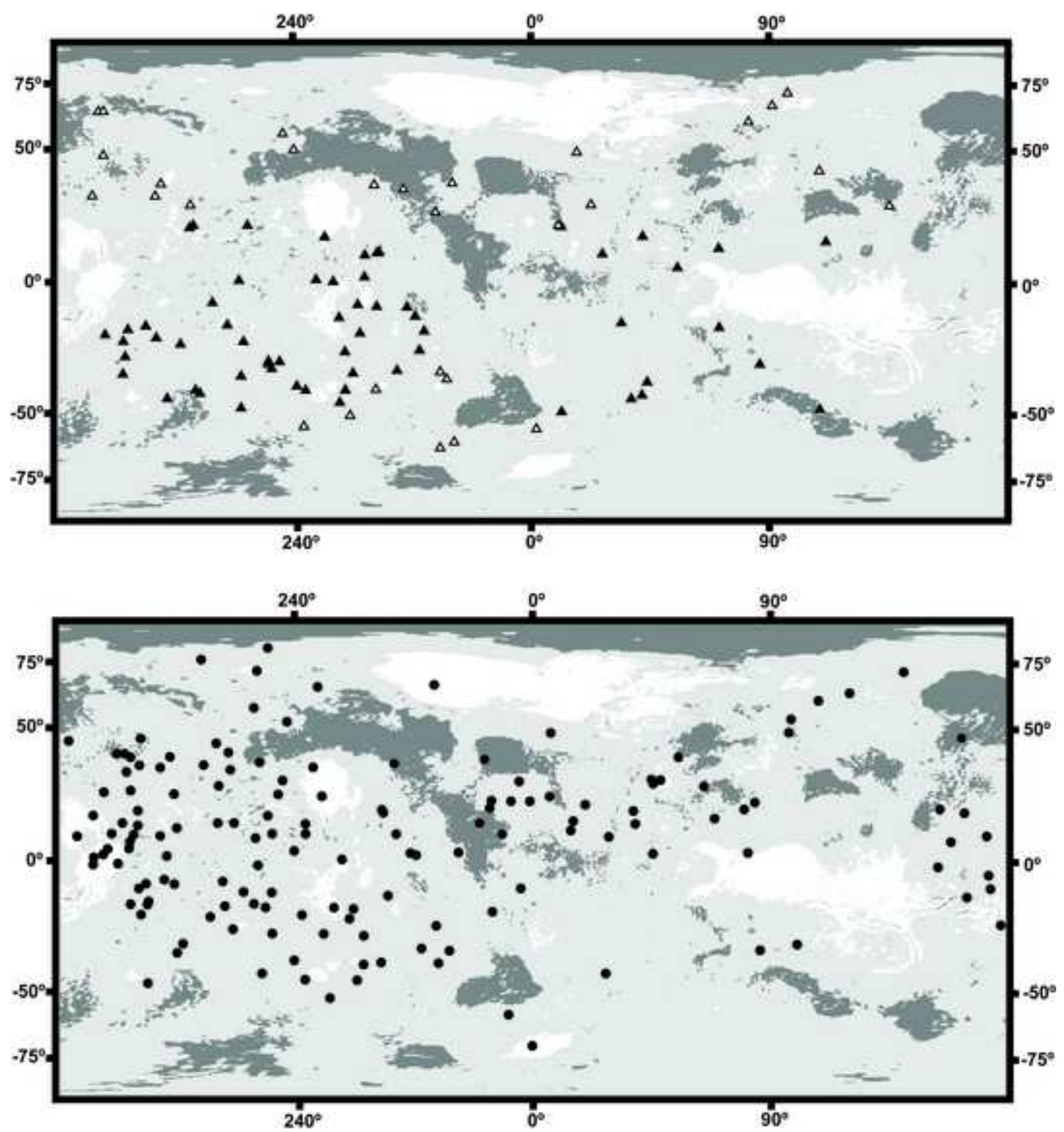

Highlands

Mesolands

$\Delta \quad$ Embayed intermediate volcanoes (Type I)

- Embayed intermediate volcanoes (Type II)

Lowlands

- Large volcanoes 
55

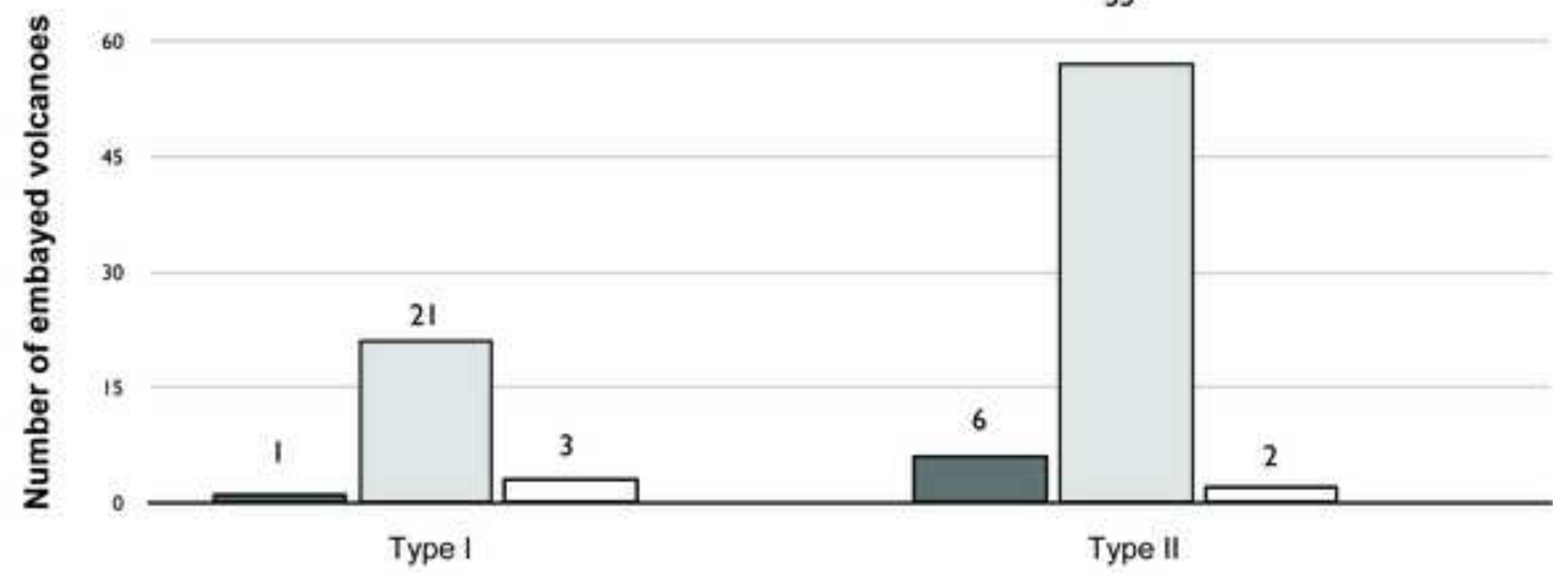

Lowlands $\quad \square$ Mesolands $\quad \square$ Highlands 


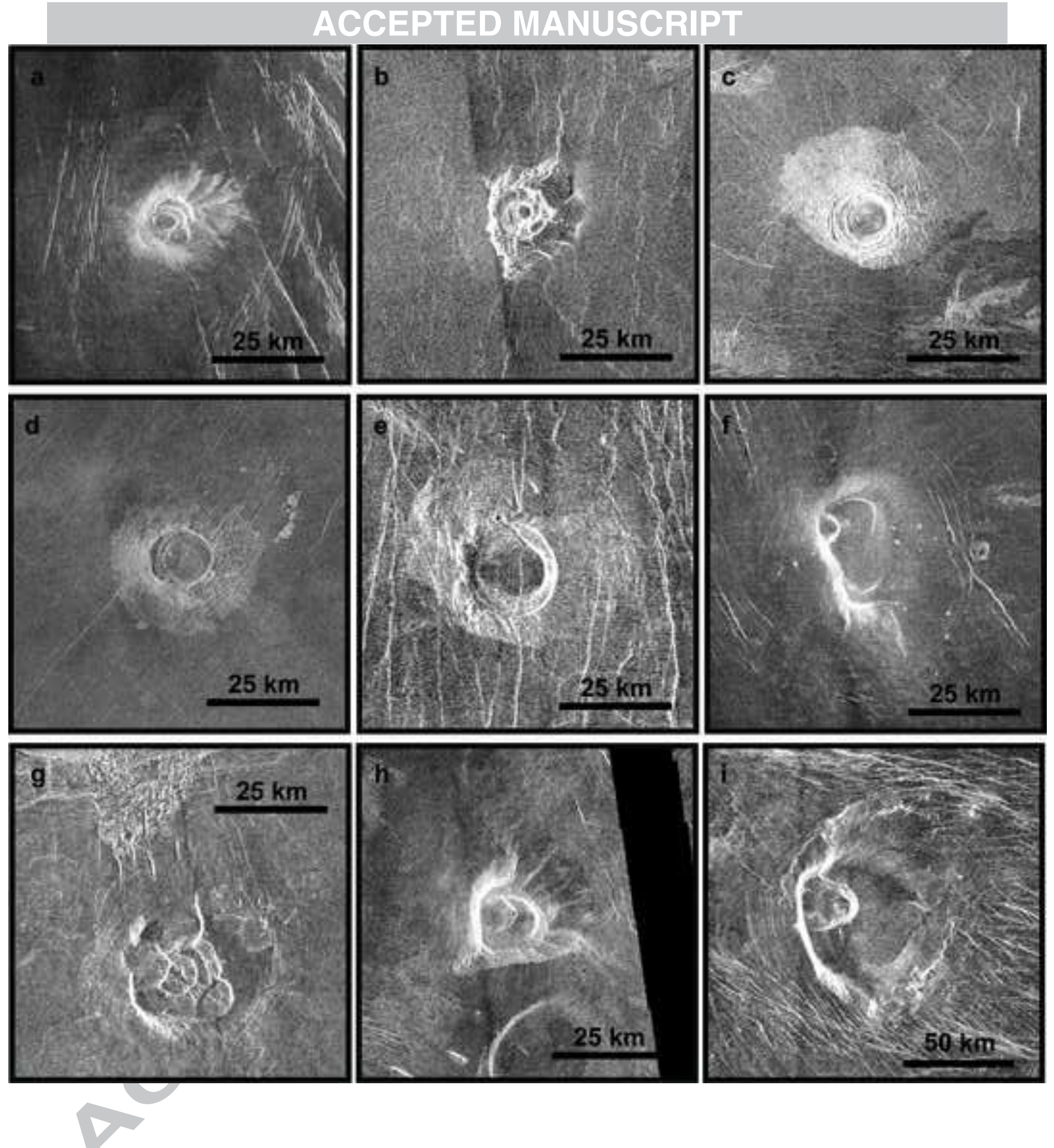




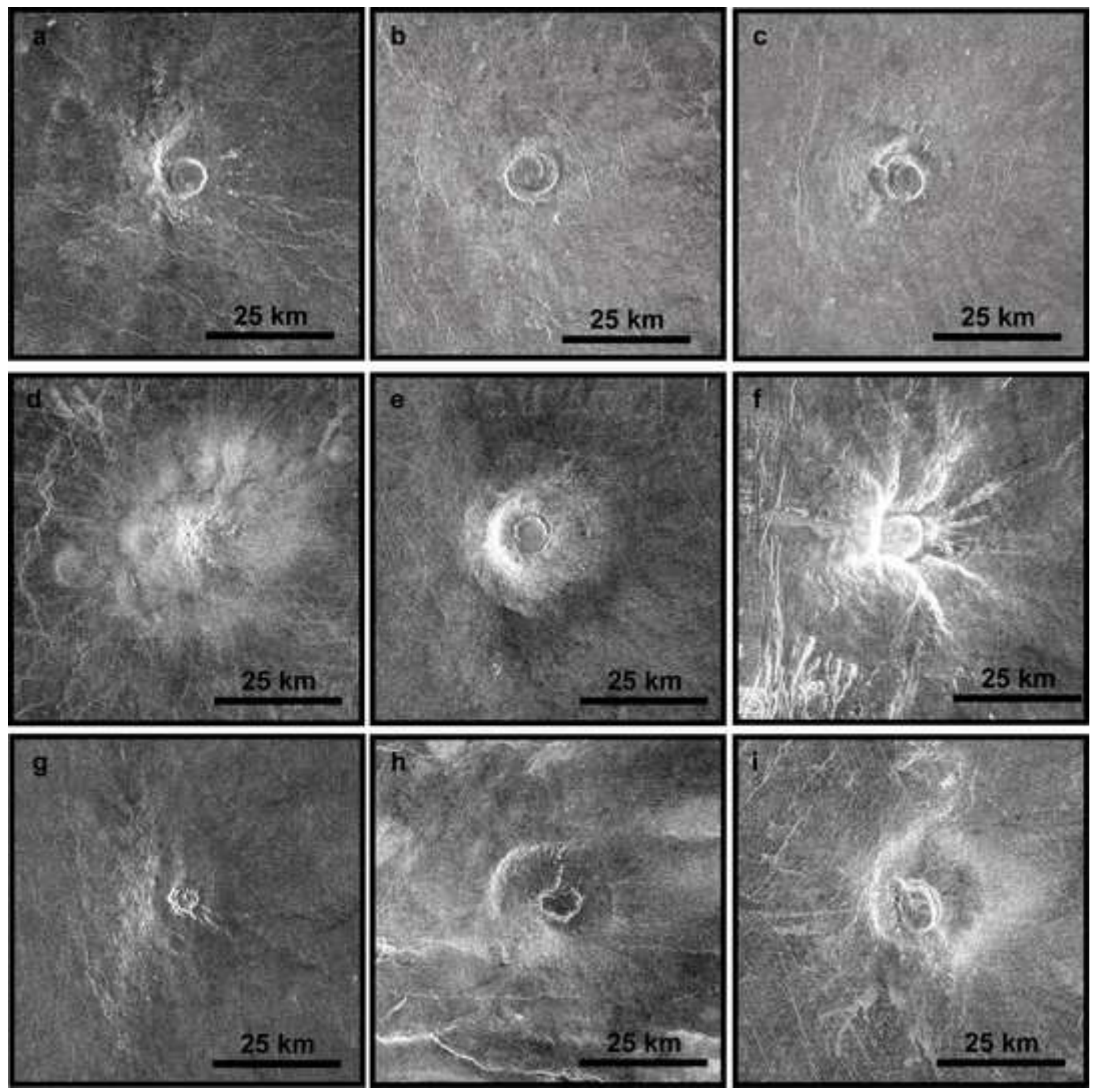


x

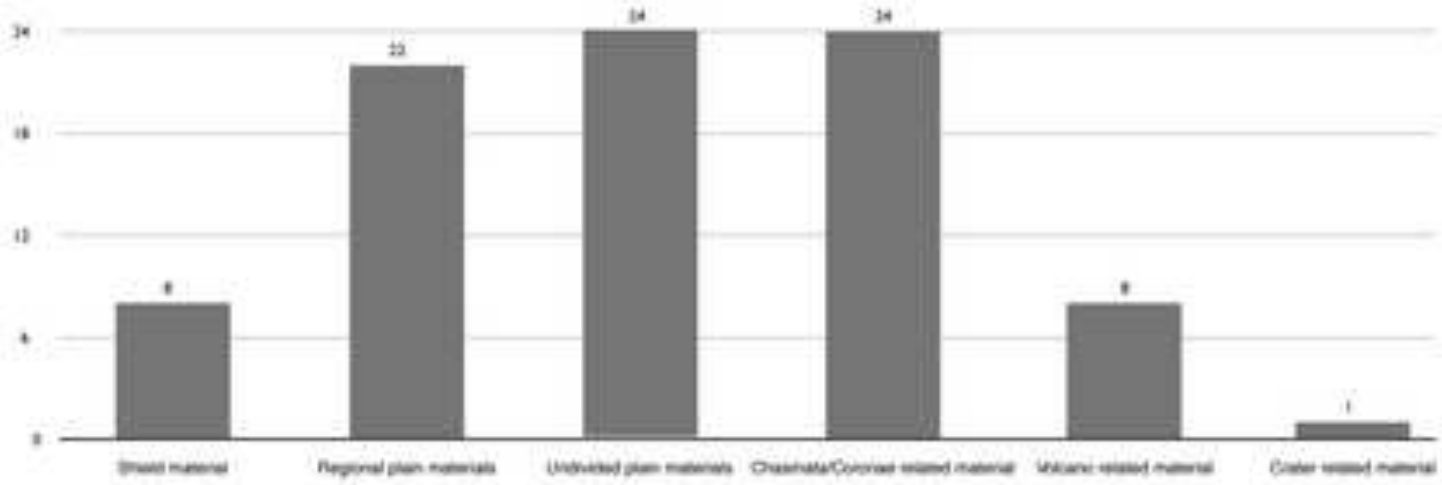




\section{ACCEPTED MANUSCRIPT}

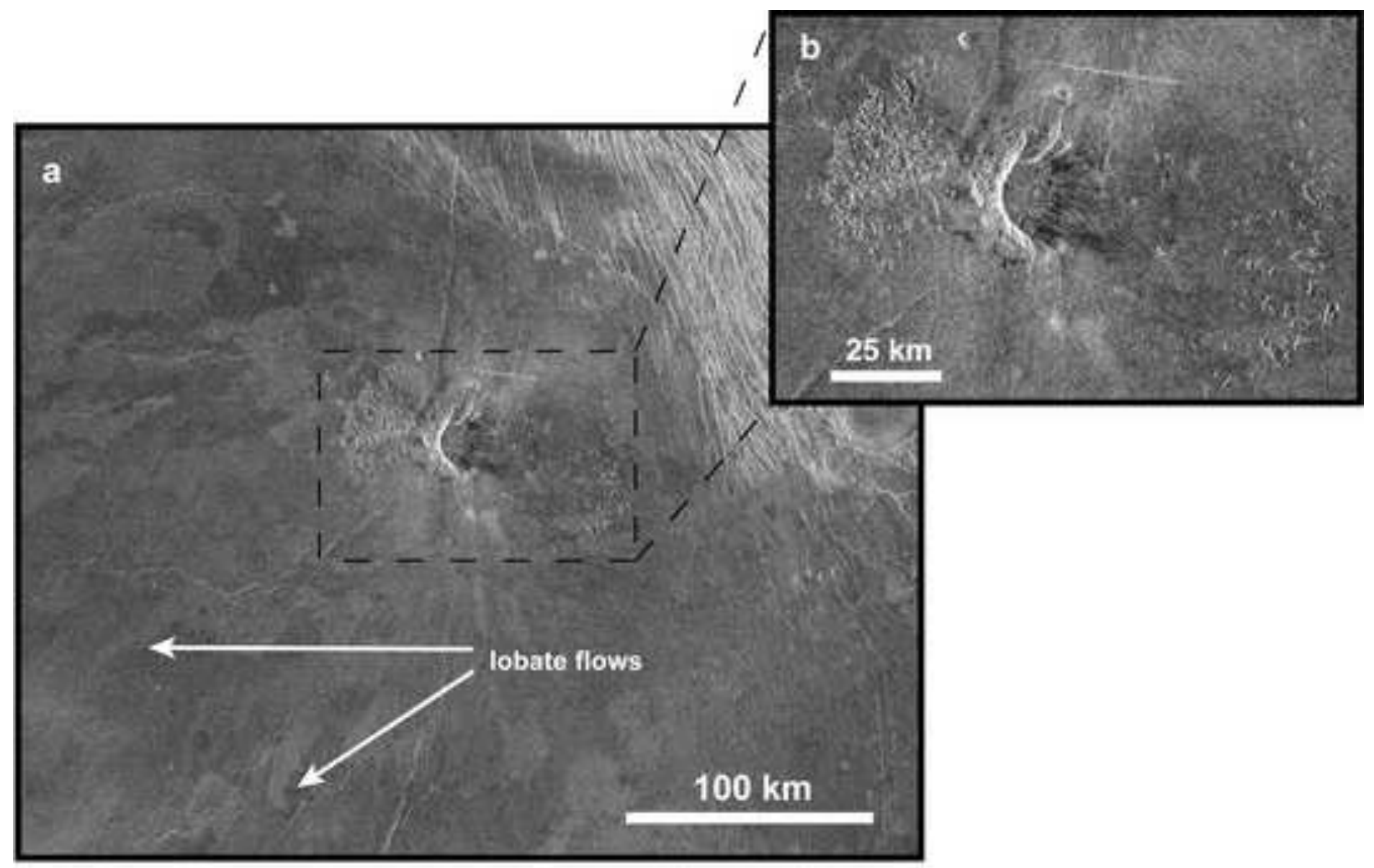

c

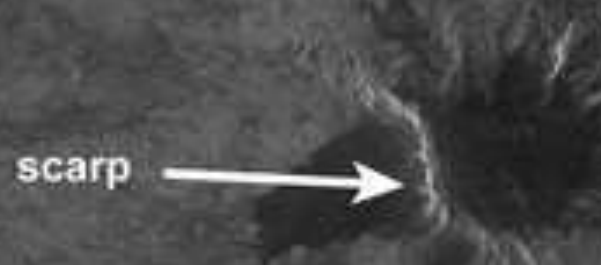

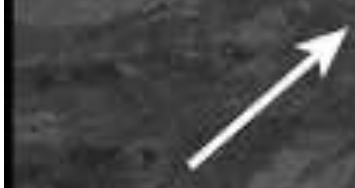

possible buried hummocky terrain 


\begin{tabular}{|c|c|c|c|c|}
\hline Coordinates & $\begin{array}{l}\text { Size } \\
(\mathbf{k m})\end{array}$ & Type & Morphology & Embayment material \\
\hline $70.5^{\circ} \mathrm{N} / 97^{\circ} \mathrm{E}^{*}$ & 97.5 & 2 & SSD & Shield plains material (unit psh; Ivanov and Head, 2008) \\
\hline $65.5^{\circ} \mathrm{N} / 91^{\circ} \mathrm{E}$ & 30 & 2 & FD & Shield plains material (unit psh; Ivanov and Head, 2008) \\
\hline $63.5^{\circ} \mathrm{N} / 196.5^{\circ} \mathrm{E}^{*}$ & 60 & 2 & FD & $\begin{array}{l}\text { Radar-bright regional plains material (unit } \mathrm{pr}_{\mathrm{a}} \text {; Rosenberg and } \\
\text { McGill, 2001) }\end{array}$ \\
\hline $63.5^{\circ} \mathrm{N} / 198^{\circ} \mathrm{E}^{*}$ & 50 & 2 & FD & $\begin{array}{l}\text { Radar-bright regional plains material (unit } \mathrm{pr}_{\mathrm{a}} \text {; Rosenberg and } \\
\text { McGill, 2001) }\end{array}$ \\
\hline $59.5^{\circ} \mathrm{N} / 82^{\circ} \mathrm{E}$ & 25 & 1 & SH & $\begin{array}{l}\text { Shield plains material (unit psh) /Regional plains material, lower } \\
\text { unit (unit } \mathrm{rp}_{1} \text { ) (Ivanov and Head, 2008) }\end{array}$ \\
\hline $55^{\circ} \mathrm{N} / 266^{\circ} \mathrm{E}^{*}$ & 30 & 1 & FD & Flows from Atira Mons \\
\hline $49^{\circ} \mathrm{N} / 270^{\circ} \mathrm{E}$ & 27 & 2 & FD & Shield plains material (unit psh; Basilevsky, 2008) \\
\hline $48^{\circ} \mathrm{N} / 17^{\circ} \mathrm{E}$ & 23 & 2 & FD & Regional plains material (unit pr; McGill, 2004a) \\
\hline $47^{\circ} \mathrm{N} / 198.5^{\circ} \mathrm{E}$ & 25 & 2 & FD & Undivided volcanic materials (regional plains) \\
\hline $41^{\circ} \mathrm{N} / 99^{\circ} \mathrm{E}$ & 25 & 2 & SSD & Undivided volcanic materials (regional plains) \\
\hline $36.5^{\circ} \mathrm{N} / 330^{\circ} \mathrm{E}^{*}$ & 34 & 2 & FD & Undivided volcanic materials (regional plains) \\
\hline $36^{\circ} \mathrm{N} / 220^{\circ} \mathrm{E}$ & 33 & 2 & FD & Flows from Sakwap-mana Mons \\
\hline $36^{\circ} \mathrm{N} / 330.5^{\circ} \mathrm{E}^{*}$ & 25 & 2 & FD & Undivided volcanic materials (regional plains) \\
\hline $33.5^{\circ} \mathrm{N} / 312^{\circ} \mathrm{E}^{*}$ & 36 & 2 & FD & Flows from Zemire Corona or associated volcanic features \\
\hline $31.5^{\circ} \mathrm{N} / 194^{\circ} \mathrm{E}$ & 30 & 1 & SH & Undivided volcanic materials (regional plains) \\
\hline $31.5^{\circ} \mathrm{N} / 218^{\circ} \mathrm{E}$ & 33 & 1 & SH & Uzume Fluctus (flows from Fea Fossae) \\
\hline $28.2^{\circ} \mathrm{N} / 22.5^{\circ} \mathrm{E}$ & 52 & 2 & FD & Regional plains material (unit pr; McGill, 2004a) \\
\hline $28^{\circ} \mathrm{N} / 231^{\circ} \mathrm{E}$ & 20 & 2 & FD & $\begin{array}{l}\text { Flows from Fea Fossae or tectomagmatic features in Ulfrum } \\
\text { Regio }\end{array}$ \\
\hline $27.5^{\circ} \mathrm{N} / 135^{\circ} \mathrm{E}$ & 25 & 2 & FD & Undivided volcanic materials (regional plains) \\
\hline $25.5^{\circ} \mathrm{N} / 324^{\circ} \mathrm{E}$ & 26 & 2 & FD & Undivided volcanic materials (regional plains) \\
\hline $21^{\circ} \mathrm{N} / 252^{\circ} \mathrm{E}$ & 20 & 2 & FD & Undivided volcanic materials (regional plains) \\
\hline $20.7^{\circ} \mathrm{N} / 10.3^{\circ} \mathrm{E}$ & 19 & 2 & FD & Regional plains material, member b (unit $\mathrm{pr}_{\mathrm{b}} ; \mathrm{McGill,} \mathrm{2000)}$ \\
\hline $20.5^{\circ} \mathrm{N} / 231.5^{\circ} \mathrm{E}^{*}$ & 23 & 2 & FD & Flows from Pani Corona or near fracture systems \\
\hline $20.2^{\circ} \mathrm{N} / 10.6^{\circ} \mathrm{E}$ & 20 & 1 & $\mathrm{SH}$ & Regional plains material, member b (unit $\mathrm{pr}_{\mathrm{b}} ; \mathrm{McGill,} \mathrm{2000)}$ \\
\hline $20^{\circ} \mathrm{N} / 230.5^{\circ} \mathrm{E}^{*}$ & 35 & 2 & FD & Flows from Pani Corona or near fracture systems \\
\hline $16.7^{\circ} \mathrm{N} / 41.3^{\circ} \mathrm{E}$ & 24 & 1 & SSD & Flow material of coronae (unit fc; Campbell and Clark, 2006) \\
\hline $16.5^{\circ} \mathrm{N} / 281.5^{\circ} \mathrm{E}$ & $15-20$ & 1 & SH & Flows from Devana Chasma \\
\hline $14.5^{\circ} \mathrm{N} / 110.7^{\circ} \mathrm{E}$ & 22 & 1 & FD & Shield terrain (unit s; Hansen, 2009) \\
\hline $12^{\circ} \mathrm{N} / 70.1^{\circ} \mathrm{E}^{*}$ & 26 & 2 & FD & Undivided volcanic materials (regional plains) \\
\hline $10.5^{\circ} \mathrm{N} / 301.5^{\circ} \mathrm{E}^{*}$ & 25 & 1 & FD & Plains-forming flow material (Crown et al., 2008) \\
\hline $10.5^{\circ} \mathrm{N} / 301^{\circ} \mathrm{E}^{*}$ & 21 & 2 & FD & Plains-forming flow material (Crown et al., 2008) \\
\hline $10^{\circ} \mathrm{N} / 26^{\circ} \mathrm{E}^{*}$ & 33 & 1 & $\mathrm{SH}$ & $\begin{array}{l}\text { Kali Mons distal flow material (unit fdK/ Regional plains } \\
\text { material, member b (unit } \mathrm{pr}_{\mathrm{b}} \text { ) (McGill, 2000) }\end{array}$ \\
\hline $9.5^{\circ} \mathrm{N} / 296.5^{\circ} \mathrm{E}^{*}$ & 25 & 2 & FD & Undivided volcanic materials (regional plains) \\
\hline $5^{\circ} \mathrm{N} / 54.5^{\circ} \mathrm{E}$ & 28 & $1>$ & SH & $\begin{array}{l}\text { Homogeneous plain material of Ovda Regio (unit phO; } \\
\text { Campbell and Clark, 2006) }\end{array}$ \\
\hline $0.5^{\circ} \mathrm{N} / 278^{\circ} \mathrm{E}^{*}$ & 15 & 2 & FD & Flows from unnamed corona in Hinemoa Planitia \\
\hline $0^{\circ} \mathrm{N} / 249^{\circ} \mathrm{E}^{*}$ & 22 & 2 & FD & Undivided volcanic materials (regional plains) \\
\hline $0.5^{\circ} \mathrm{S} / 284.5^{\circ} \mathrm{E}^{*}$ & $18-20$ & 2 & FD & Regional plains (unit pr; Senske, 2006) \\
\hline $8.5^{\circ} \mathrm{S} / 239^{\circ} \mathrm{E}$ & 25 & 2 & FD & Dhorani Corona flow material (unit fD; Brian et al., 2005) \\
\hline $9^{\circ} \mathrm{S} / 294^{\circ} \mathrm{E}^{*}$ & 20 & 2 & SH & Regional plains (unit pr; Senske, 2006) \\
\hline $10^{\circ} \mathrm{S} / 312.5^{\circ} \mathrm{E}^{*}$ & 35 & 2 & $\mathrm{SH}$ & Flows from Aleksota Mons \\
\hline $13.5^{\circ} \mathrm{S} / 315.5^{\circ} \mathrm{E}^{*}$ & 26 & 2 & SH & Flows from Panina Patera \\
\hline $14^{\circ} \mathrm{S} / 286.5^{\circ} \mathrm{E}^{*}$ & 20 & 1 & $\mathrm{SH}$ & Regional plains (unit pr; Senske, 2006) \\
\hline $16^{\circ} \mathrm{S} / 33.5^{\circ} \mathrm{E}$ & 17 & 2 & FD & Undivided volcanic materials (regional plains) \\
\hline $16.5^{\circ} \mathrm{S} / 244.5^{\circ} \mathrm{E}^{*}$ & 25 & 1 & SH & Corona material, unit k (unit $\mathrm{co}_{\mathrm{k}} ;$ Chapman, 1999) \\
\hline $17.3^{\circ} \mathrm{S} / 213.5^{\circ} \mathrm{E}^{*}$ & 31 & 2 & FD & Rzhanitsa Corona flow material (unit cR; Brian et al., 2005) \\
\hline $18^{\circ} \mathrm{S} / 70.5^{\circ} \mathrm{E}$ & 20 & 1 & $\mathrm{SH}$ & Undivided volcanic materials (regional plains) \\
\hline $18.5^{\circ} \mathrm{S} / 207.5^{\circ} \mathrm{E}$ & 20 & 2 & FD & Undivided volcanic materials (regional plains) \\
\hline $19^{\circ} \mathrm{S} / 319^{\circ} \mathrm{E}$ & 20 & 2 & FD & Undivided volcanic materials (regional plains) \\
\hline $20^{\circ} \mathrm{S} / 295^{\circ} \mathrm{E}^{*}$ & $19-20$ & 2 & SSD & Regional plains (unit pr; Senske, 2006) \\
\hline $20.5^{\circ} \mathrm{S} / 198.5^{\circ} \mathrm{E}^{*}$ & 21 & 2 & FD & Flows from coronae of Jokwa Linea \\
\hline $21.5^{\circ} \mathrm{S} / 218^{\circ} \mathrm{E}$ & $18-20$ & 2 & FD & Lineated plains material (unit pli; Brian et al., 2005) \\
\hline $23^{\circ} \mathrm{S} / 205^{\circ} \mathrm{E}$ & 25 & 2 & FD & Undivided volcanic materials (regional plains) \\
\hline $23^{\circ} \mathrm{S} / 250^{\circ} \mathrm{E}$ & 28 & 2 & FD & Corona material, unit m (unit $\mathrm{co}_{\mathrm{m}} ;$ Chapman, 1999) \\
\hline $24^{\circ} \mathrm{S} / 227^{\circ} \mathrm{E}$ & 24 & 2 & $\mathrm{SH}$ & Fedchenko Patera flow material (unit fF; Brian et al., 2005) \\
\hline $26.5^{\circ} \mathrm{S} / 317.2^{\circ} \mathrm{E}$ & 35 & 2 & FD & Undivided volcanic materials (regional plains) \\
\hline $27^{\circ} \mathrm{S} / 289^{\circ} \mathrm{E}$ & 22 & 2 & FD & Undivided volcanic materials (regional plains) \\
\hline $29^{\circ} \mathrm{S} / 206^{\circ} \mathrm{E}$ & 25 & 1 & SSD & Isabella Crater related material; Bleamaster, 2007,2008 \\
\hline $30.8^{\circ} \mathrm{S} / 264.2^{\circ} \mathrm{E}$ & 20 & 1 & $\mathrm{SH}$ & $\begin{array}{l}\text { Flows from fractures and coronae of Parga Chasmata (unit fchP; } \\
\text { López and Hansen, 2008) }\end{array}$ \\
\hline $31.5^{\circ} \mathrm{S} / 260.2^{\circ} \mathrm{E}$ & 15 & 1 & SH & $\begin{array}{l}\text { Flows from fractures and coronae of Parga Chasmata (unit fchP; } \\
\text { López and Hansen, 2008) }\end{array}$ \\
\hline $31.7^{\circ} \mathrm{S} / 85.7^{\circ} \mathrm{E}$ & 22 & 2 & FD & Aino fractured plains material (unit pfA; Stofan and Guest, \\
\hline
\end{tabular}




\begin{tabular}{|c|c|c|c|c|}
\hline & & & & 2003) \\
\hline $31.8^{\circ} \mathrm{S} / 260.5^{\circ} \mathrm{E}^{*}$ & 26 & 2 & FD & $\begin{array}{l}\text { Flows from fractures and coronae of Parga Chasmata (unit fchP; } \\
\text { López and Hansen, 2008) }\end{array}$ \\
\hline $32.2^{\circ} \mathrm{S} / 260.5^{\circ} \mathrm{E}^{*}$ & 20 & 2 & FD & $\begin{array}{l}\text { Flows from fractures and coronae of Parga Chasmata (unit fchP; } \\
\text { López and Hansen, 2008) }\end{array}$ \\
\hline $33.5^{\circ} \mathrm{S} / 261.5^{\circ} \mathrm{E}^{*}$ & 30 & 2 & FD & $\begin{array}{l}\text { Flows from fractures and coronae of Parga Chasmata (unit fchP; } \\
\text { López and Hansen, 2008) }\end{array}$ \\
\hline $34.2^{\circ} \mathrm{S} / 308.8^{\circ} \mathrm{E}$ & 15 & 2 & FD & Undivided volcanic materials (regional plains) \\
\hline $35^{\circ} \mathrm{S} / 292^{\circ} \mathrm{E}$ & 27 & 2 & FD & Flows from coronae or fractures on Parga Chasmata \\
\hline $35.4^{\circ} \mathrm{S} / 205.2^{\circ} \mathrm{E}$ & 18 & 1 & SH & Regional plains material; Bleamaster, 2007,2008 \\
\hline $35^{\circ} \mathrm{S} / 325.8^{\circ} \mathrm{E}$ & 36 & 2 & FD & Flows from Innini Mons \\
\hline $36.3^{\circ} \mathrm{S} / 249.8^{\circ} \mathrm{E}$ & 27 & 1 & $\mathrm{SH}$ & $\begin{array}{l}\text { Flow material from Monoshi Tholus (unit ftMo; López and } \\
\text { Hansen, 2008) }\end{array}$ \\
\hline $37.3^{\circ} \mathrm{S} / 328^{\circ} \mathrm{E}$ & 25 & 2 & FD & Undivided volcanic materials (regional plains) \\
\hline $38.2^{\circ} \mathrm{S} / 43.2^{\circ} \mathrm{E}$ & 27 & 1 & $\mathrm{SH}$ & Shield terrain (unit s; Hansen and Tharalson, in press) \\
\hline $40^{\circ} \mathrm{S} / 271^{\circ} \mathrm{E}^{*}$ & 26 & 2 & FD & Undivided volcanic materials (regional plains) \\
\hline $41.5^{\circ} \mathrm{S} / 232.5^{\circ} \mathrm{E}$ & 28 & 2 & FD & Undivided volcanic materials (regional plains) \\
\hline $41.5^{\circ} \mathrm{S} / 274^{\circ} \mathrm{E}^{*}$ & 24 & 2 & FD & Undivided volcanic materials (regional plains) \\
\hline $41.5^{\circ} \mathrm{S} / 289^{\circ} \mathrm{E}^{*}$ & 24 & 2 & FD & Flows from coronae or fractures on Parga Chasmata \\
\hline $41.5^{\circ} \mathrm{S} / 301.2^{\circ} \mathrm{E}$ & 25 & 2 & FD & Undivided volcanic materials (regional plains) \\
\hline $42.5^{\circ} \mathrm{S} / 234.2^{\circ} \mathrm{E}$ & 35 & 1 & $\mathrm{SH}$ & Undivided volcanic materials (regional plains) \\
\hline $43.2^{\circ} \mathrm{S} / 41.2^{\circ} \mathrm{E}$ & 25 & 2 & FD & Shield terrain (unit s; Hansen and Tharalson, in press) \\
\hline $43.5^{\circ} \mathrm{S} / 41^{\circ} \mathrm{E}$ & 21 & 2 & FD & Shield terrain (unit s; Hansen and Tharalson, in press) \\
\hline $44.5^{\circ} \mathrm{S} / 212^{\circ} \mathrm{E}^{*}$ & 25 & 2 & $\mathrm{SH}$ & Undivided volcanic materials (regional plains) \\
\hline $44.8^{\circ} \mathrm{S} / 37.2^{\circ} \mathrm{E}$ & 26 & 1 & SH & $\begin{array}{l}\text { Ubastet Fluctus and Astkhik Planum flow material (unit fUA; } \\
\text { Hansen and Tharalson, in press) }\end{array}$ \\
\hline $46^{\circ} \mathrm{S} / 287^{\circ} \mathrm{E}^{*}$ & 33 & 2 & FD & Flows from Nzambi Corona \\
\hline $48^{\circ} \mathrm{S} / 249.8^{\circ} \mathrm{E}$ & 21 & 1 & SH & $\begin{array}{l}\text { Helen Planitia materials, undivided (unit pHu; López and } \\
\text { Hansen, 2008) }\end{array}$ \\
\hline $48.6^{\circ} \mathrm{S} / 108.3^{\circ} \mathrm{E}$ & 35 & 1 & $\mathrm{SH}$ & Regional plains (unit pr; Senske, 2008) \\
\hline $49^{\circ} \mathrm{S} / 10.8^{\circ} \mathrm{E}$ & 27 & 2 & FD & $\begin{array}{l}\text { Lineated regional plains material (unit prl; McGill and Bridges, } \\
\text { 2002) }\end{array}$ \\
\hline $51^{\circ} \mathrm{S} / 291.5^{\circ} \mathrm{E}^{*}$ & 23 & 2 & FD & Flows from Tareshmat Corona \\
\hline $56.3^{\circ} \mathrm{S} / 2.1^{\circ} \mathrm{E}$ & 80 & 1 & $\mathrm{SH}$ & Flows from Eithinoha Corona or near fracture systems \\
\hline $61.5^{\circ} \mathrm{S} / 331^{\circ} \mathrm{E}^{*}$ & 65 & 2 & FD & Rift zone unit (unit rt; Ivanov and Head, 2006) \\
\hline $63.5^{\circ} \mathrm{S} / 325.5^{\circ} \mathrm{E}^{*}$ & 40 & 2 & FD & Rift zone unit (unit rt; Ivanov and Head, 2006) \\
\hline
\end{tabular}

Table I. List of the embayed intermediate volcanoes determined in the study (coordinates, type of embayed volcano, morphology and embayment material). Asterisk marks the examples present in Crumpler and Aubele (2000). 
Research highlights.

- Study of the global population of embayed intermediate volcanoes that could be old large volcanoes

- Determination of the embaying materials

- Implications for the evolution of the volcanic plains: large volcanoes occur throughout the formation of the volcanic plains

- Discussion on the classification of volcanic features based in size. 